Stress controls on transport properties of the Mercia Mudstone Group: Importance for hydrocarbon depletion and $\mathrm{CO} 2$ injection

J.F. Harrington, C.C. Graham, E. Tamayo-Mas, D. Parkes

DOI: 10.1016/j.marpetgeo.2018.02.009

Reference: JMPG 3237

To appear in: Marine and Petroleum Geology

Please cite this article as: Harrington, J.F., Graham, C.C., Tamayo-Mas, E., Parkes, D., Stress controls on transport properties of the Mercia Mudstone Group: Importance for hydrocarbon depletion and $\mathrm{CO} 2$ injection, Marine and Petroleum Geology (2018), doi: 10.1016/j.marpetgeo.2018.02.009. 


\title{
Stress controls on transport properties of the Mercia Mudstone Group: importance for hydrocarbon depletion and $\mathrm{CO}_{2}$ injection
}

\section{Authors}

J.F. Harrington, C.C. Graham, E. Tamayo-Mas and D. Parkes.

\author{
Affiliations \\ British Geological Survey
}

\section{Addresses}

British Geological Survey, Environmental Science Centre, Nicker Hill, Keyworth, Nottingham, UK.

J.F. Harrington (jfha@bgs.ac.uk)

\begin{abstract}
The physical properties of the Mercia Mudstone Group (MMG) are of interest to Carbon Capture and Storage (CCS) in the UK, both in terms of the sealing capacity of certain horizons and in order to assess scenarios involving $\mathrm{CO}_{2}$ migration in the overburden above potential CCS sites. In this study, the hydromechanical properties of MMG samples from the Larne Basin, Northern Ireland, were directly measured under steady-state conditions. Test samples were found to be good seals, with hydraulic permeabilities ranging from $\approx 2.1 \times 10^{-18}$ to $8.4 \times 10^{-21} \mathrm{~m}^{2}\left(2.1 \times 10^{-3}\right.$ to $\left.8.5 \times 10^{-6} \mathrm{mD}\right)$. A detailed examination of the consolidation behaviour of the material yielded values for compressibility, hydraulic permeability and specific storage, as a function of effective pressure. Consolidation testing also provided preconsolidation pressure values of between 30 and $37 \mathrm{MPa}$. Test data were fitted to a linear elastic model using a two-dimension finite element approach, yielding hydraulic permeability and Young's Modulus, as a function of effective pressure. Findings suggest localisation of flow, due to small-scale heterogeneity, may play a role even in relatively large test samples. Results also highlight the impact of methodology on resulting permeabilities and the importance of using values measured at boundary conditions appropriate for the specific application. Critical state envelopes were derived from test data and used to conduct a scenario analysis, considering a range of stress paths, to examine the impacts of depletion and reinflation during $\mathrm{CO}_{2}$ injection. Initial stress conditions, stress path gradient and caprock heterogeneity were all found to be influencing factors on the potential for yield during depletion and the resulting deformation mode. The response to $\mathrm{CO}_{2}$ injection is less clear, but will be impacted by the initial caprock permeability and resulting drainage response. An awareness of these controls on caprock performance during stress path changes may aid in the selection of depleted CCS sites with geomechanically favourable characteristics for reinjection.
\end{abstract}

\section{Keywords}

Mercia Mudstone, caprock, CCS, critical state yield envelope, permeability, elastic moduli

\section{Introduction}


Understanding material response to changes in stress is relevant to many reservoir scenarios, particularly towards the end of production. It is also important for future Carbon Capture and Storage (CCS) schemes, during reinjection, especially in scenarios where the stress-state is close to the yield envelope (Harrington et al. 2011). In particular, the reuse of depleted hydrocarbon reservoir for CCS may provide certain advantages, such as well-constrained geology and pre-existing infrastructure (Mott McDonald, 2012), but prior stress history during hydrocarbon production may have an impact on the reservoir and surrounding rock (Zoback, 2010). Stress changes during depletion may cause compaction, reactivation of faults, subsidence and/or damage to infrastructure (Hettema et al., 2002; Segall, 1985; 1989; 1998) though the response to further stress changes on reinjection is less well known. The hydromechanical properties of caprock materials, such as clays and shales, are highly dependent on the stress history to which they have previously been exposed. Void ratio, permeability and the elastic moduli are all dependent on effective pressure. Nevertheless, although a substantial body of work exists examining stress path dependency on the material properties of reservoirs (Jones et al., 1986; Holt et al., 1991; Schutjens et al., 2004; Hangx et al., 2013; Lynch et al., 2013; Cuss et al., 2016), there is a limited amount of experimental evidence examining the influence of stress history on caprock behaviour.

The objectives of this study were to examine the influence of effective pressure cycling on the hydromechanical properties of the Mercia Mudstone Group (MMG), a sealing succession belonging to Triassic hydrocarbon fields and potential $\mathrm{CO}_{2}$ storage sites in the southern North Sea and in the Irish Sea. These results form part of a larger project, CONTAIN (the impaCt of hydrOcarbon depletioN on the Treatment of cAprocks within performance assessment for $\mathrm{CO}_{2}$ InjectioN schemes).

Direct measurement of hydraulic permeability in tight, clay-rich lithologies is non-trivial (Yang and Aplin et al. 2007), due to the exceptionally small flow rates expected at realistic in situ conditions. Achieving steady-state flow can be time consuming, especially for larger, more representative sample volumes. As a result, availability of direct permeability measurements in tight mudstones and shales is limited and values are often inferred from petrophysical properties, though recent findings indicate a need for caution for this approach when used with new data-sets where permeabilities fall below $1 \times 10^{-19} \mathrm{~m}^{2}$ (Busch and Hildenbrand, 2013). Availability of direct permeability, $k$, measurements in MMG samples under in situ conditions is exceptionally limited.

A large amount of hydraulic and physical properties data relating to the MMG is available within the engineering geology community (Hobbs et al., 2002). However, the majority of this information relates to material derived from shallow depths, where weathering and meteoric water-flow have impacted on the physical properties of the material. Typically, measured permeabilities are higher than for geological seals in a hydrocarbons context. More recently, Armitage et al. (2016) examined permeabilities of MMG samples taken from the Willow Farm borehole, East Midlands. They measured $k$ at varying effective pressures, which varied from around $1 \times 10^{-16}$ to $1 \times 10^{-19} \mathrm{~m}^{2}$. However, the changes in void ratio leading to permeability reduction on loading were not measured, meaning that the preconsolidation pressure could not be estimated. Data in relation to the consolidation state of the MMG is limited. Some information is derived from the engineering geology sector, where it is generally described as 'heavily overconsolidated' in nature (Chandler, 1969), though this is a relative term and is used in the context of the shallow subsurface. There is, therefore, a severe lack of data in relation to the mechanical response of the MMG at burial depths appropriate to CCS targets in offshore Ireland and the UK. 
In this study we describe the MMG material tested and the experimental procedure, before presenting experimental findings, which include quantification of the effective pressure dependency of void ratio, intrinsic permeability, specific storage, compressibility and elastic moduli for the MMG samples. Values for preconsolidation pressure, associated with the maximum burial depth during compaction, are also given. A numerical approach is used to model test data and facilitate interpretation of the results. Finally, a critical state mechanics analysis is conducted, considering the potential for yield for a range of stress path scenarios.

\section{Material and methods}

\subsection{Stratigraphic context}

The Mercia Mudstone was deposited in a number of small, fault-bounded, subsiding basins (e.g. E. Irish Sea, Cheshire, E. Midlands) across the UK, during the mid-late Triassic. Generically the unit was deposited in a paleo-mud-flat environment, but due to variations in subsidence level, sediment source and fluvial input, the unit is both lithologically and stratigraphically variable (Hobbs et al., 2002). A detailed review of mineralogical analyses of the Mercia Mudstone Group (MMG) is provided by Hobbs et al. (2002). Primary non-clay minerals observed include quartz, calcium and magnesium carbonates, calcium sulphates, micas, iron oxides and halite. There may also be feldspar and some very small quantities of heavy minerals present. The clay fraction within the Mercia Mudstone is primarily composed of illite, chlorite and mixed layer clays (illite-smectite, chloritesmectite), although in some horizons pure smectite may also be found.

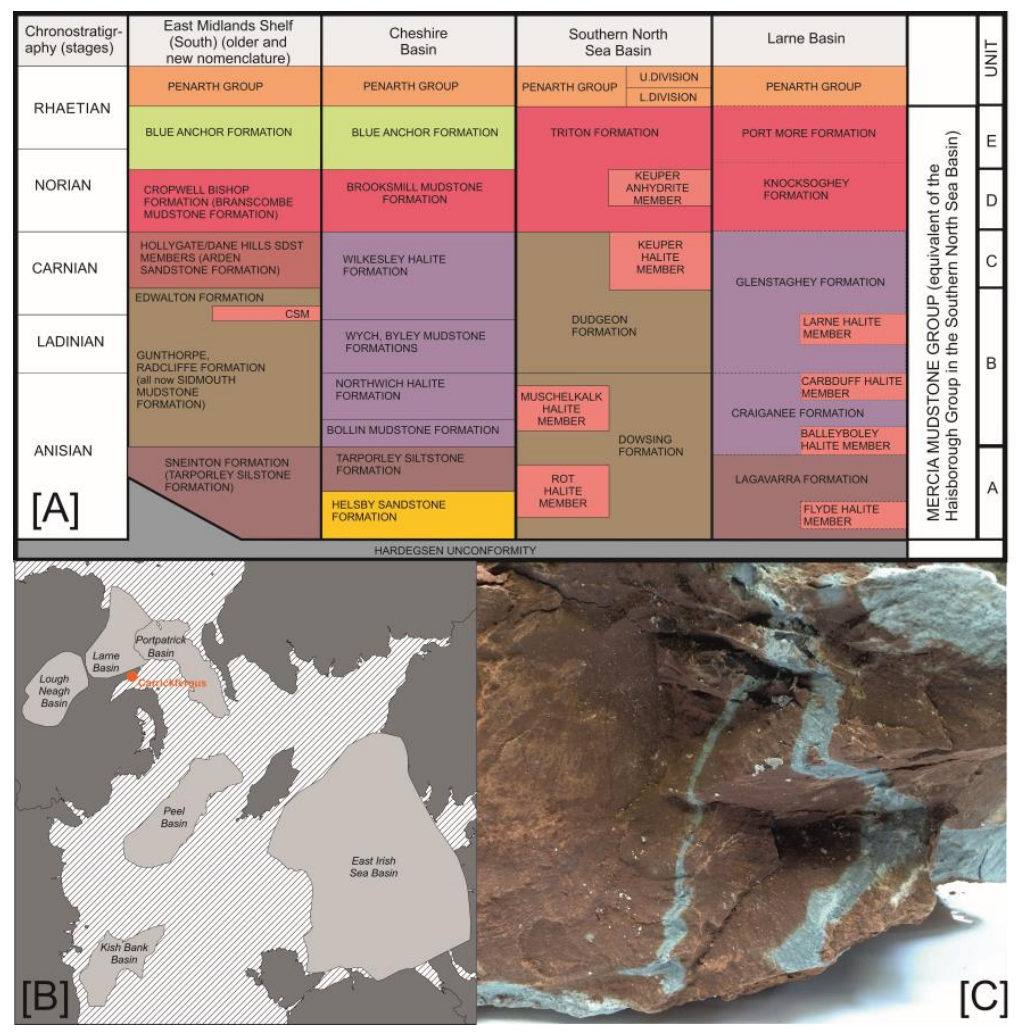

Figure 1. [A] Stratigraphic correlation of the Mercia Mudstone Group across key UK basins, as synthesised from Manning and Wilson (1975), Wilson (1993), Johnson et al. (1994), Hobbs et al. (2002) and Howard et al. (2008). [B] Map showing the sampling location at Carrickfergus in 


\section{relation to the Larne Basin and others in the region. [C] Test material in hand-specimen, displaying typical blue colouration in bleached zones.}

The MMG is of interest both as overburden and as a potential sealing succession for $\mathrm{CO}_{2}$ storage sites both in the UK and Ireland. Three primary reservoirs for CCS have been identified within the Southern North Sea (Bentham, 2006): (i) the Bunter Sandstone Formation (Triassic), (ii) the Leman Sandstone Formation (Early Permian) and (iii) Silesian sandstones (Carboniferous). A large number of closed structures within the Bunter Sandstone Formation (BSF) saline aquifer have been identified as having potential to store $\mathrm{CO}_{2}$ (Bentham, 2006). The BSF is also the reservoir for several gas fields (e.g., the Hewett, Esmond, Forbes and Gordon fields), although their capacity is generally much less significant. The basal seal for the BSF is the Triassic Bunter Shale formation (Williams et al., 2014). The upper seal is formed by the overlying Haisborough group, the offshore equivalent of the MMG (Figure 1A). The nature of the primary seal varies depending on location, and can be formed by a number of different lithologies within the Dowsing Formation of the lower Haisborough Group, an argillaceous unit which includes anhydrite and beds of dolomite, along with two main bedded halite units (Johnson et al. 1994). The Röt Halite Member forms the primary seal to hydrocarbons in the Esmond Gas Field Complex (Ketter, 1991), but is absent in the vicinity of the Hewett Fields where anhydritic mudstones form an effective top seal (Cooke-Yarbrough, 1991).

Lewis et al. (2009) provide an overview of possible $\mathrm{CO}_{2}$ storage sites for Ireland and the UK. Off the West coast of Britain, the Permo-Triassic deposits of the Central Irish Sea and East Irish Sea Basins are of particular interest (Lewis et al., 2009). Within these, the storage potential of the Sherwood Sandstone Group (SSG) and sealing capability of the MMG are inferred by the established hydrocarbons industry within the East Irish Sea Basin. The Lower Triassic Ormskirk Sandstone is present basin-wide, forming the reservoir for most hydrocarbons found in this basin to date (Seedhouse and Racey, 1997). This reservoir formation is sealed by the Upper Triassic MMG. These mudstones were deposited in ephemeral lakes after Atlantic rifting ceased and contain inter-bedded evaporites. The sequence of the MMG members varies across the basin, with increasing sand content and pinching-out of the halite towards the basin margins.

Whilst the MMG is considered as a regional caprock, the sealing unit within the group differs from the northern to the southern parts of the basin, with halite forming an excellent hydrocarbon seal in some locations, whilst the sandstone is capped by mudstone in others. A general reduction in the thickness and number of evaporate beds in the upper part of the MMG, highlights the importance of careful assessment of the sealing characteristics of mudstones within the group.

\subsection{Test material}

Whilst core material from the MMG is available in the British Geological Survey on- and off-shore borehole collection, as is often the case, the material has been allowed to dehydrate and has not been kept in a suitable state of preservation to conduct a meaningful assessment of physical properties. This combined with sample concerns in relation to the high degree of fine-scale heterogeneity within the MMG and the requirement for testing a representative elementary volume, made use of archive material an unsuitable option. Instead, fresh material was collected during excavation of a new mine drift in Northern Ireland, which sits on the Southern margins of the Larne Basin (Figure 1B). This represented a unique and limited opportunity to collect fresh material from the MMG at depth and below the weathered zone, in advance of the permanent grouting of 
the rockwall. Collected material was sealed in durable foil under vacuum and stored in refrigerated conditions, so as to minimise desaturation and microbial degradation.

Samples were prepared by dry-drilling with a diamond-tipped core. Since water should not be used as drilling fluid for such materials, frictional effects were reduced by use of compressed air. Finally cylindrical samples were turned on a lathe to the chosen final diameter and the ends were faced-off perpendicular to the cylinder length. Care was taken to work as quickly as possible, in order to reduce the impact of sample drying. All test samples were cut with the core axis perpendicular to bedding. Final sample dimensions are presented in Table 1. These dimensions increase the likelihood that bulk properties (as opposed to damaged material) are measured during flow testing. Offcuts taken during sample preparation were weighed immediately, then placed in an oven and exposed to a temperature of $105^{\circ} \mathrm{C}$ for more than one day (following standard geotechnical procedures), before re-weighing. The results provide additional geotechnical data (Table 1), including void ratio, dry and bulk density and water saturation.

\begin{tabular}{|c|c|c|c|c|c|c|c|}
\hline Sample & $\begin{array}{l}\text { Length } \\
(\mathrm{mm})\end{array}$ & $\begin{array}{l}\text { Diameter } \\
(\mathrm{mm})\end{array}$ & $\begin{array}{l}\text { Moisture } \\
\text { content } \\
(\%)\end{array}$ & $\begin{array}{c}\text { Bulk } \\
\text { density } \\
\left(\mathrm{Mg} \cdot \mathrm{m}^{-3}\right)\end{array}$ & 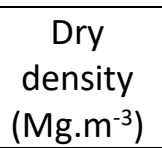 & $\begin{array}{l}\text { Void } \\
\text { ratio }\end{array}$ & $\begin{array}{c}\text { Water } \\
\text { saturation } \\
(\%)\end{array}$ \\
\hline Mercia-1 & 36.8 & 53.7 & 10.8 & 2.30 & 2.07 & 0.313 & 93.6 \\
\hline Mercia-2 & 38.9 & 54.3 & 10.9 & 2.32 & 2.10 & 0.299 & 99.4 \\
\hline Mercia-3 & 48.8 & 50.0 & 10.8 & 2.35 & 2.11 & 0.288 & $\sim 100$ \\
\hline
\end{tabular}

Table 1. Pre-test geotechnical properties for each Mercia sample. Data for Mercia-1 are based on off-cut material. Values determined using an average grain density of $2.722 \mathrm{Mg} \cdot \mathrm{m}^{-3}$ measured using BS 1377: Part 2: 1990, Test 8.4.

Petrological analysis was conducted on samples of the recovered test material from the edge of the Larne Basin (Figure 1C), taken from $57 \mathrm{~m}$ depth within the upper Knocksoghey Formation (Figure 1A). At hand specimen scale the material is well-preserved, unweathered and offers a good representation of the Mercia Mudstone formations present in the entire Larne basin and not just of the Knocksoghey Formation. It can be described as a homogenous fine-grained, well-consolidated, reddish-brown mudstone with abundant bluish-green patches and veins of mudstone-containing reduced iron. The sample was also studied optically and can be predominantly described as a muddy dolomite microsparstone, but varies from dolomite microsparstone to silty dolomitic mudstone (classification after Hallsworth and Knox, 1999).

\subsection{Experimental set-up}

Testing was undertaken using a BGS custom-designed isotropic permeameter. The apparatus is described in detail by Harrington and Horseman (1999) and consists of five main components: (1) a specimen assembly, (2) a $70 \mathrm{MPa}$ rated pressure vessel and associated confining pressure system, (3) a fluid injection system, (4) a backpressure system, and (5) a National Instruments data acquisition system. The specimen is subject to an isotropic confining pressure, and independent pore pressure transducers, placed on the injection and backpressure lines, allow the system to be monitored for systematic drift. The cylindrical specimen is sandwiched between two end-caps and jacketed in heatshrink Teflon to exclude confining fluid and provide a flexible pressure seal. A unique 'lock-ring' arrangement (Figure 2 ) is then placed over the jacketed specimen, so as to provide a leak-tight seal. 
The inlet and outlet zones for permeant flow through the specimen are provided by porous filter discs ( $50 \mathrm{~mm}$ in diameter) that are recessed into the bearing surface of the end-caps.

Volumetric flow rates were controlled or monitored using a pair of ISCO-260, Series D, syringe pumps operated from a single digital control unit. The position of each pump piston is determined by an optically encoded disc graduated in segments equivalent to a change in volume of $16.6 \mathrm{nl}$. Movement of the pump piston is controlled by a micro-processor which continuously monitors and adjusts the rate of rotation of the encoded disc using a DC-motor connected to the piston assembly via a geared worm drive. This allows each pump to operate in either constant pressure or constant flow modes. A programme written in LabVIEW ${ }^{\mathrm{TM}}$ elicited data from each pump at pre-set time intervals. Testing was performed in an air-conditioned laboratory at a nominal temperature of $20^{\circ} \mathrm{C}$.

All pressure sensors were calibrated against laboratory standards by applying incremental steps in pressure, from atmospheric to a pre-determined maximum value. This was followed by a descending sequence to quantify any hysteresis. Least-squares fits were calculated and the regression parameters used to correct raw data.

To minimise possible osmotic swelling of samples, a synthetic pore-water solution was prepared for use as the backpressure fluid and as the permeant during all hydraulic tests. In the absence of porefluid composition data, a salt-saturated solution was made using crushed halite from close in the succession to the sampling location. Each experiment consisted of a hydration phase, an initial hydraulic test and a consolidation phase, Table 2.

Volume change of the sample was derived by monitoring in- and out-flow, as confining stress was either incremented or decremented. Because pressure within the injection and backpressure monitoring systems were maintained constant as confining pressure was changed, compliance of the apparatus and measurement system, and its impact on the measured volume of fluid displaced from the sample, was negligible. Instantaneous changes in volume of test components (i.e. tubing and filters) caused by incremental changes in confining stress, were extremely small. This is evidenced through inspection of transient flow response (presented in Section 3.2.1 which shows minimal instantaneous volume change at the start of each stress step. This seems reasonable as the bulk modulus of stainless steel is substantially greater than that of the test material and the stress regime imposed in this study was relatively small ( $<70 \mathrm{MPa}$ ). The influence of apparatus response on fluid displacements was, therefore, assessed as negligible. 


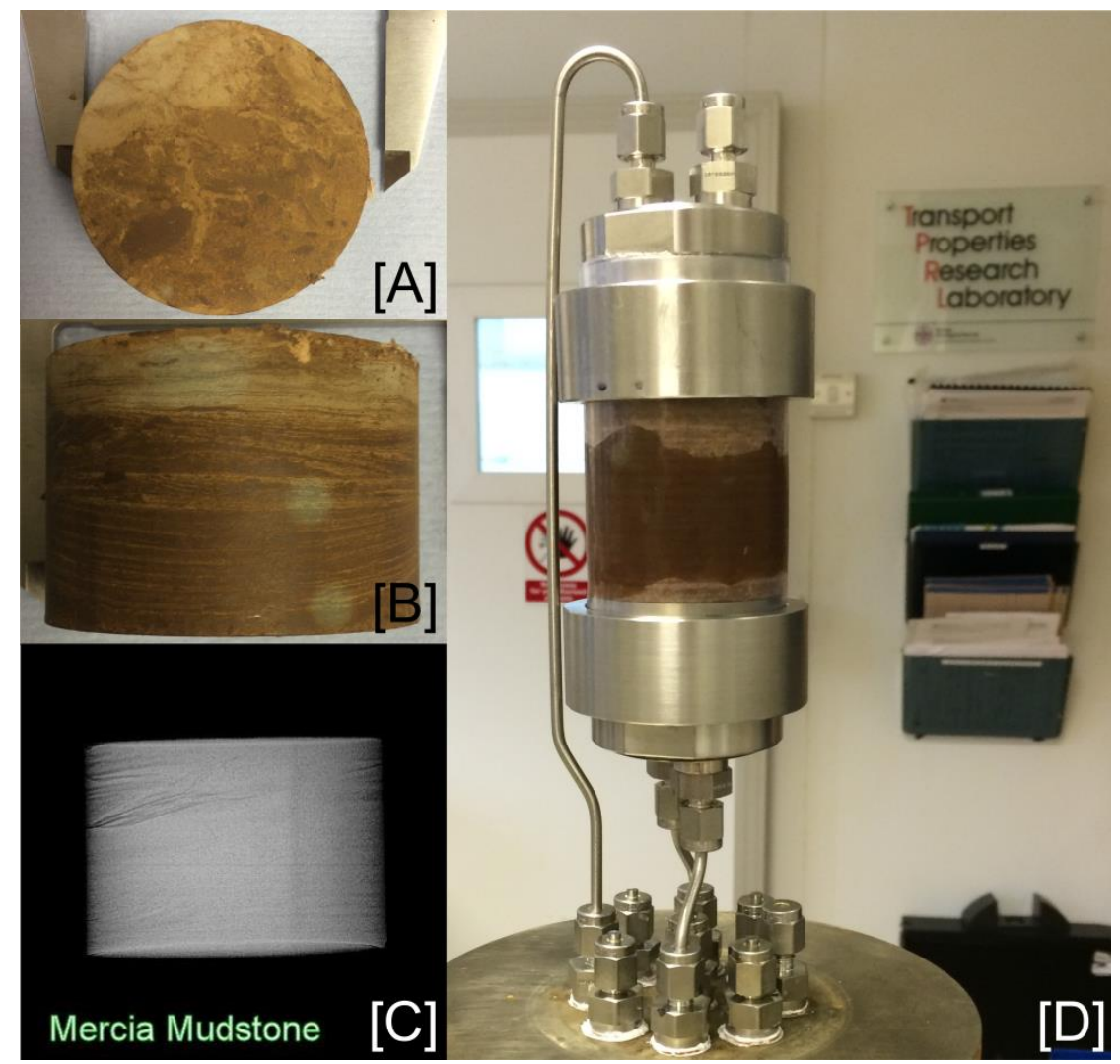

Figure 2. $[A]$ and $[B]$ A sample from the Mercia Mudstone Group after preparation, $[C]$ 2D x-ray image of an MMG sample and [D] a sample arranged within the isotropic test assembly.

\begin{tabular}{|l|c|c|c|c|}
\hline $\begin{array}{l}\text { Test and stage } \\
\text { number }\end{array}$ & Type & $\begin{array}{c}\text { Confining } \\
\text { pressure } \\
\text { (MPa) }\end{array}$ & $\begin{array}{c}\text { Injection } \\
\text { pressure } \\
\text { (MPa) }\end{array}$ & $\begin{array}{c}\text { Backpressure } \\
\text { (MPa) }\end{array}$ \\
\hline Mercia-1 [0] & EQ & 14.0 & 1.0 & 1.0 \\
\hline Mercia-1 [1] & CO & 23.0 & 1.0 & 1.0 \\
\hline Mercia-1 [2] & CO & 32.0 & 1.0 & 1.0 \\
\hline Mercia-1 [3] & CO & 41.0 & 1.0 & 1.0 \\
\hline Mercia-1 [4] & CO & 23.0 & 1.0 & 1.0 \\
\hline Mercia-1 [5] & CO & 41.0 & 1.0 & 1.0 \\
\hline Mercia-1 [6] & CO & 50.0 & 1.0 & 1.0 \\
\hline Mercia-1 [7] & CO & 23.0 & 1.0 & 1.0 \\
\hline Mercia-1 [8] & CO & 50.0 & 1.0 & 1.0 \\
\hline Mercia-1 [9] & CO & 59.0 & 1.0 & 1.0 \\
\hline Mercia-2 [0] & EQ & 14.0 & 1.0 & 1.0 \\
\hline Mercia-2 [1] & CO & 23.0 & 1.0 & 1.0 \\
\hline Mercia-2 [2] & CO & 32.0 & 1.0 & 1.0 \\
\hline Mercia-2 [3] & CO & 41.0 & 1.0 & 1.0 \\
\hline Mercia-2 [4] & CO & 50.0 & 1.0 & 1.0 \\
\hline Mercia-2 [5] & CO & 59.0 & 1.0 & 1.0 \\
\hline Mercia-3 [0] & EQ & 14.0 & 1.0 & 1.0 \\
\hline Mercia-3 [0-B] & CPT & 14.0 & 3.0 & 1.0 \\
\hline Mercia-3 [1] & CO & 23.0 & 1.0 & 1.0 \\
\hline
\end{tabular}




\begin{tabular}{|l|c|c|c|c|}
\hline Mercia-3 [1-B] & CPT & 23.0 & 3.0 & 1.0 \\
\hline Mercia-3 [2] & CO & 32.0 & 1.0 & 1.0 \\
\hline Mercia-3 [2-B] & CPT & 32.0 & 3.0 & 1.0 \\
\hline Mercia-3 [3] & CO & 41.0 & 1.0 & 1.0 \\
\hline Mercia-3 [3-B] & CPT & 41.0 & 3.0 & 1.0 \\
\hline Mercia-3 [4] & CO & 50.0 & 1.0 & 1.0 \\
\hline Mercia-3 [4-B] & CPT & 50.0 & 3.0 & 1.0 \\
\hline Mercia-3 [5] & CO & 59.0 & 1.0 & 1.0 \\
\hline Mercia-3 [5-B] & CPT & 59.0 & 3.0 & 1.0 \\
\hline Mercia-3 [6] & CO & 68.0 & 1.0 & 1.0 \\
\hline Mercia-3 [6-B] & CPT & 68.0 & 3.0 & 1.0 \\
\hline Mercia-3 [7] & CO & 41.0 & 1.0 & 1.0 \\
\hline Mercia-3 [7-B] & CPT & 41.0 & 3.0 & 1.0 \\
\hline Mercia-3 [8] & CO & 23.0 & 1.0 & 1.0 \\
\hline Mercia-3 [8-B] & CPT & 23.0 & 3.0 & 1.0 \\
\hline Mercia-3 [9] & CO & 14.0 & 1.0 & 1.0 \\
\hline Mercia-3 [9-B] & CPT & 14.0 & 3.0 & 1.0 \\
\hline
\end{tabular}

Table 2 Summary of experimental histories showing sample and stage numbers, type of stage (EQ = equilibration, $\mathrm{CPT}=$ constant pressure test and $\mathrm{CO}=$ consolidation confining pressure, $\mathrm{MPa}$ ), injection pressure and backpressure.

\section{Results and discussion}

\subsection{Rehydration and equilibration}

Initial test conditions were selected based on an approximate depth to top of reservoir of $1 \mathrm{~km}$, assuming an overburden density of $2.3 \mathrm{~g} / \mathrm{cm}^{3}$ (Hobbs et al., 2002) and an applied pore-water pressure, $p_{p}$, of $10 \mathrm{MPa}$, resulting in an applied effective pressure, $p^{\prime}$, of $13 \mathrm{MPa}$. After applying confinement, both up-stream and down-stream filters were flushed and saturated with pore-water solution before a constant water pressure was applied to both ends of the sample and allowed to equilibrate, Table 2 . The purpose of this test stage was to fully saturate the rock and allow each specimen to reach hydraulic equilibrium under the selected initial effective pressure. The hydration phase was followed by consolidation testing of the three MMG samples, under the test conditions outlined in Table 2.

\subsection{Consolidation response}

The transport properties of rocks and sediments are intrinsically interlinked with fabric and porosity. These characteristics are directly related to burial and exhumation history, particularly in weaker materials such as mudstone. As a sediment is buried, the resulting increase in effective pressure leads to consolidation, by way of compaction and dewatering processes, and a reduction in void ratio, which in turn impacts hydraulic conductivity. A previously loaded sediment will, therefore, retain a 'memory' of prior loading up to the previously experienced pressure.

The void ratio, $e$, is defined as the ratio of the volume of voids to the total volume of the sample. It is related to porosity, $\phi$, by:

$$
\phi=\frac{e}{1+e}
$$


where $e$ and $\phi$ are dimensionless. In soil mechanics, conventionally, the consolidation response of a clay is considered in terms of the change in void ratio resulting from a change in the logarithm of effective pressure, $p^{\prime}$, (Schofield and Wroth, 1968; Atkinson and Bransby, 1978). In $e$-In $p^{\prime}$ space, the response of an unconsolidated clay to loading can be described in terms of consolidation along the 'Virgin Compression Line' (VCL) and unloading along the 'Rebound/Recompression Line' (RRL) (Figure $3 A)$. A clay which has been previously consolidated, will plot below the VCL, until it is loaded above the maximum effective pressure it was previously subjected to, known as the 'preconsolidation pressure', or $p_{c}^{\prime}$.
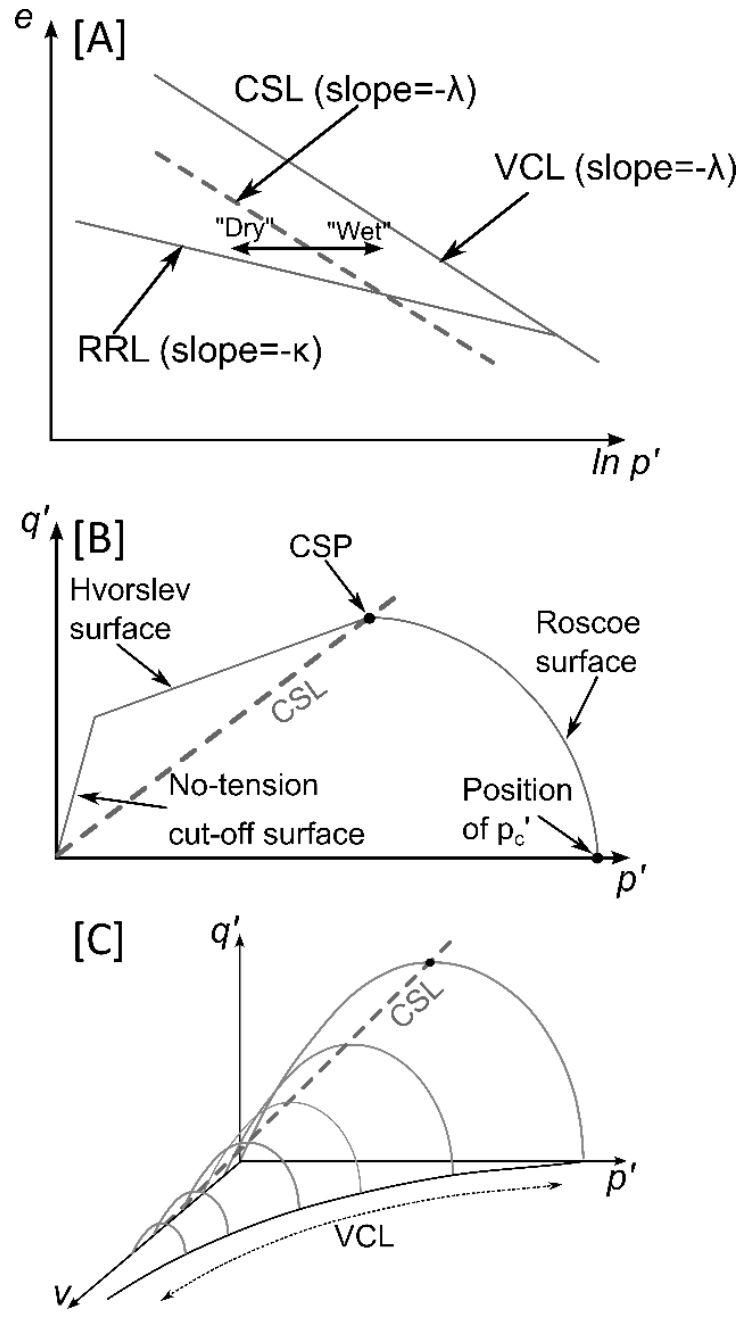

Figure 3. Idealised yield behaviour of porous materials as a function of void ratio, $e$, effective pressure, $p^{\prime}$, and differential stress, $q^{\prime}$. [A] for a clay in $e$-In $p^{\prime}$ space (after Horseman et al., 1993), [B] for a clay in $p^{\prime}=q^{\prime}$ space. [C] Idealised behaviour of a lithified sediment in $p^{\prime}-q^{\prime}-v$ space, showing the modified envelope of Sheldon et al. (2006). CSP=Critical State Point, CSL=Critical State Line, VCL=Virgin Consolidation Line and RRL=rebound/Recompression Line.

The consolidation response for the MMG test samples is shown in the $e-\ln p^{\prime}$ space in Figure 4 . The solid lines represent the behaviour of the samples when confining pressure is increased and backpressure held constant, while the dashed lines represent the behaviour of the samples when confining pressure is decreased. These curves can be represented by the expressions 


$$
e=e_{0}-\lambda \ln \left(\frac{p^{\prime}}{p_{0}^{\prime}}\right)
$$

for the VCL and

$$
e=e_{0}-\kappa \ln \left(\frac{p^{\prime}}{p_{0}^{\prime}}\right)
$$

for the RRL,

where $-\lambda$ and $-\kappa$ are the slopes of the $V C L$ and the RRL respectively, $e_{0}$ is the void ratio intercept at an effective pressure $p_{0}^{\prime}=1.0 \mathrm{MPa}$ (Schofield and Wroth, 1968). Values for $\lambda, \kappa, e$ and $p^{\prime}$ are presented in Tables 3 and 4. Examination of the data indicates consistent behaviour, with average values for the VCL and RRL slopes presented in Table 4. The clear differences in estimated slopes for Mercia-3, as compared to the other samples, are likely related to its selection from a different lithofacies within the MMG.

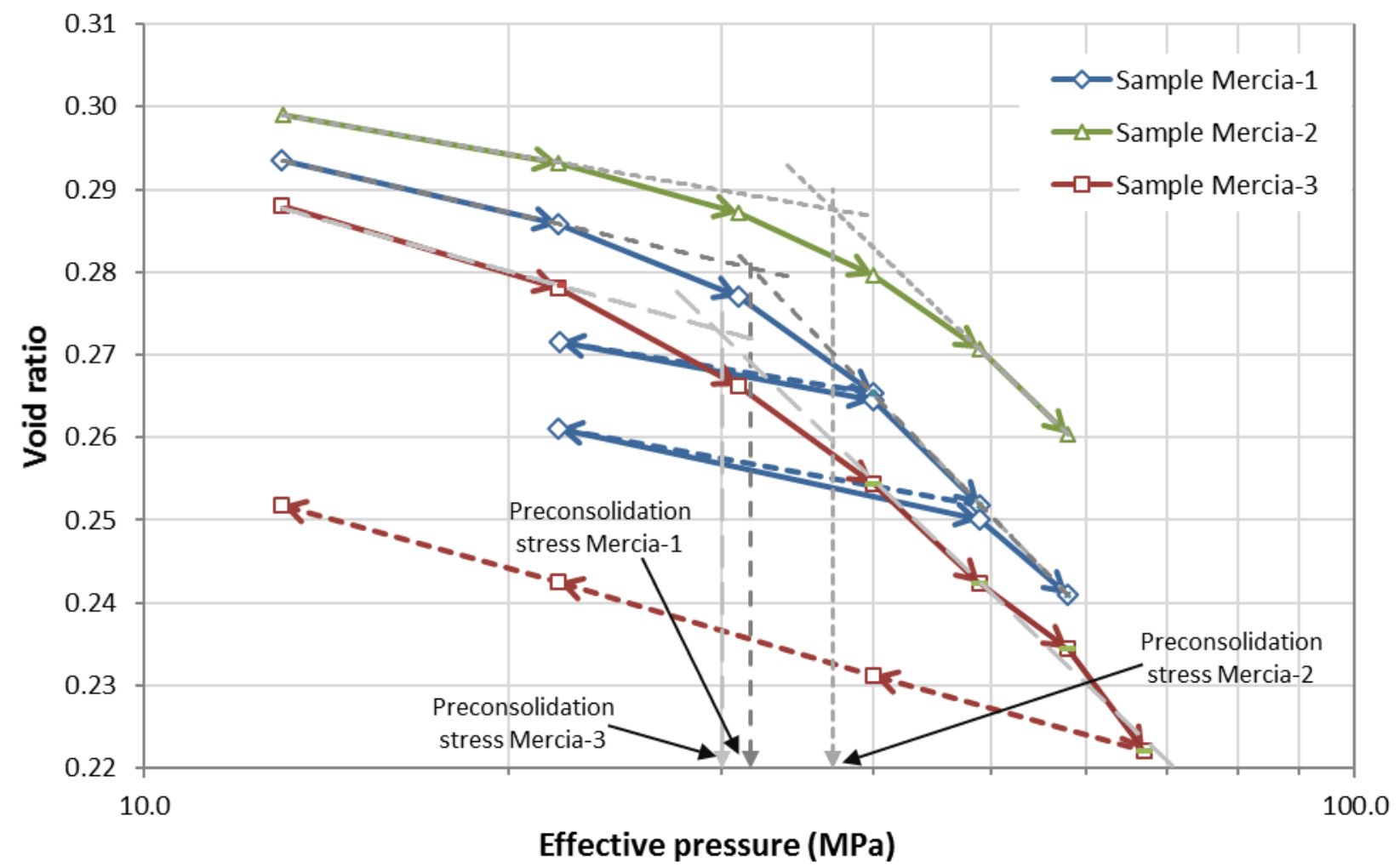

Figure 4. Void ratio versus effective pressure data, showing approach taken to define values for the preconsolidation pressure for samples Mercia-1 through -3.

\begin{tabular}{|l|c|c|c|}
\hline $\begin{array}{l}\text { Test and } \\
\text { stage } \\
\text { number }\end{array}$ & $\begin{array}{c}\text { Effective } \\
\text { pressure } \\
\text { (MPa) }\end{array}$ & $\begin{array}{c}\text { Negative slope } \\
\text { of consolidation } \\
\text { curve }\end{array}$ & Nature of the volumetric strain \\
\hline Mercia-1 [1] & 22.0 & 0.015 & Reconsolidation in the overconsolidated domain \\
\hline
\end{tabular}




\begin{tabular}{|c|c|c|c|}
\hline Mercia-1 [2] & 31.0 & 0.026 & $\begin{array}{l}\text { Plastic volumetric yielding close to preconsolidation } \\
\text { pressure }\end{array}$ \\
\hline Mercia-1 [3] & 40.0 & 0.046 & Consolidation in the normally consolidated domain \\
\hline Mercia-1 [4] & 22.0 & 0.010 & \multirow{2}{*}{$\begin{array}{l}\text { Quasi-elastic rebound in the overconsolidated } \\
\text { domain }\end{array}$} \\
\hline Mercia-1 [5] & 40.0 & 0.012 & \\
\hline Mercia-1 [6] & 49.0 & 0.062 & Consolidation in the normally consolidated domain \\
\hline Mercia-1 [7] & 22.0 & 0.012 & \multirow{2}{*}{$\begin{array}{l}\text { Quasi-elastic rebound in the overconsolidated } \\
\text { domain }\end{array}$} \\
\hline Mercia-1 [8] & 49.0 & 0.014 & \\
\hline Mercia-1 [9] & 58.0 & 0.054 & Consolidation in the normally consolidated domain \\
\hline Mercia-2 [1] & 22.0 & 0.011 & Reconsolidation in the overconsolidated domain \\
\hline Mercia-2 [2] & 31.0 & 0.018 & \multirow{2}{*}{$\begin{array}{l}\text { Plastic volumetric yielding close to preconsolidation } \\
\text { pressure }\end{array}$} \\
\hline Mercia-2 [3] & 40.0 & 0.030 & \\
\hline Mercia-2 [4] & 49.0 & 0.044 & \multirow[t]{2}{*}{ Consolidation in the normally consolidated domain } \\
\hline Mercia-2 [5] & 58.0 & 0.061 & \\
\hline Mercia-3 [1] & 22.0 & 0.019 & Reconsolidation in the overconsolidated domain \\
\hline Mercia-3 [2] & 31.0 & 0.034 & $\begin{array}{l}\text { Plastic volumetric yielding close to preconsolidation } \\
\text { pressure }\end{array}$ \\
\hline Mercia-3 [3] & 40.0 & 0.046 & \multirow[t]{4}{*}{ Consolidation in the normally consolidated domain } \\
\hline Mercia-3 [4] & 49.0 & 0.060 & \\
\hline Mercia-3 [5] & 58.0 & 0.047 & \\
\hline Mercia-3 [6] & 67.0 & 0.085 & \\
\hline Mercia-3 [7] & 40.0 & 0.018 & \multirow{3}{*}{$\begin{array}{l}\text { Quasi-elastic rebound in the overconsolidated } \\
\text { domain }\end{array}$} \\
\hline Mercia-3 [8] & 22.0 & 0.019 & \\
\hline Mercia-3 [9] & 13.0 & 0.018 & \\
\hline
\end{tabular}

Table 3 Negative slope of the consolidation line in the $e$-In $\boldsymbol{p}^{\prime}$ space for various pressure ranges. For each stage the type of deformation behaviour is noted.

\begin{tabular}{|c|c|c|}
\hline Sample & Virgin consolidated line $\lambda$ & Rebound-reconsolidation line $\kappa$ \\
\hline Mercia-1 & 0.05401 & 0.01194 \\
\hline Mercia-2 & 0.05224 & 0.01090 \\
\hline Mercia-3 & 0.05959 & 0.01831 \\
\hline
\end{tabular}

Table 4 Average values for normally consolidated and rebound-reconsolidation lines for the MMG samples. The difference in values noted for Mercia-3 stem most likely relate to lithological variation.

\subsubsection{Preconsolidation pressure $\left(p_{c}^{\prime}\right)$, coefficient of volume change $\left(m_{v}\right)$ and the coefficient of consolidation $\left(c_{v}\right)$}

While the consolidation response of the MMG is well-defined (Figure 4), there are insufficient data points during yield to accurately identify the tangent line and thereby employ Casagrande's method for determining the preconsolidation pressure (Scott, 1980). As such, we propose a simpler approach based on the projection of the rebound-reconsolidation and virgin consolidation lines, defining the preconsolidation pressure as the point of intersection between the two lines (Figure 5B). Using this 
approach, values for the preconsolidation pressure for samples Mercia-1 through -3 are $31.7 \mathrm{MPa}$, 37.1 MPa and 30.0 MPa respectively.

Assuming a linear lithostatic gradient and an average overburden density of $\sim 2.3 \mathrm{~g} / \mathrm{cm}^{3}$ (Hobbs et al., 2002) estimated preconsolidation values in the 30.0-37.1 MPa would suggest a previous maximum burial depth of the order of 1.3-1.6 km. Nevertheless, it should be noted that this approximation does not allow for the potential impacts of diagenesis or the role of differential stress. According to consolidation theory, effective pressure alone will not lead to yield until this previous maximum consolidation pressure is superseded. As such, it may be assumed that yield resulting from a reduction in pore pressure on depletion is not likely to occur in this horizon of the MMG below 30 MPa. However, it should be noted that this assumes negligible influence of differential stress. Such an approach should therefore only be used with caution. The influence of differential stress is considered in greater detail in the Discussion section. In addition, test samples were recovered from the basin margin and may exhibit different preconsolidation properties compared with those from deep basinal locations.

Since many materials exhibit overconsolidated behaviour, it is convenient to define the $e$-ln $p^{\prime}$ curve in terms of the coefficient of volume change, $m_{v}$, also known as the coefficient of compressibility (Scott et al. 1980; Horseman et al. 1996). This parameter is defined as the change in unit volume, $d V$, per unit change in effective pressure

$$
m_{v}=-\frac{1}{V_{o}} \frac{d V}{d p^{\prime}}
$$

where $V_{o}$ is the initial volume of the sample. Values for $m_{v}$, derived from each increment/decrement in pressure, are presented in Table 5.

The coefficient of consolidation $c_{v}$ [ $\mathrm{m}^{2} /$ year] can be derived from analysis of the consolidation transients, Figure 5A. In Taylor's square root of time method, as described by Scott (1980), outflow is plotted versus the square root of time, as shown in Figure 5B. When viewed in this way, the early part of this curve is approximately linear. The intersection of this line with the asymptote $y=$ $\max$ (outflow) defines a value $\sqrt{t^{*}}$ that can be used to determine the coefficient $c_{v}$ as

$$
c_{v}=\frac{\pi d^{2}}{4 t^{*}}
$$

where $d$ is half the length of the sample.

The coefficient of consolidation for each sample is also presented in Table 5. However, it is important to note that these values are approximate as not all tests asymptote, i.e. reach $100 \%$ flow expelled (Figure 5A), even after 33 days. In some stages, for example Mercia-1 stage 6 and 9, Mercia-2 stage 3, 4, 5 and Mercia- 3 stage 6 , this is a coarse assumption, and thus, the derived consolidation coefficients should be considered as indicative only. This phenomenon may result from secondary compression or creep, not represented in Terzaghi's consolidation theory which forms the basis of Taylor's root time analysis method (Whitlow, 2001). However, the fact that a number of responses do reach well-defined asymptotes (e.g. stage 4, 5, 7, 8 and 9), suggests that possible leakage from the apparatus plays a negligible role in the total response of the sample during testing. 


\begin{tabular}{|c|c|c|c|c|c|c|c|}
\hline $\begin{array}{l}\text { Sample and } \\
\text { stage }\end{array}$ & $\begin{array}{c}\text { Effective } \\
\text { pressure } p^{\prime} \\
\text { (MPa) }\end{array}$ & Void ratio $e$ & $\begin{array}{l}\text { Coefficient of } \\
\text { volume } \\
\text { compressibility } \\
m_{v}\left(\mathrm{~Pa}^{-1}\right)\end{array}$ & $\begin{array}{c}\text { Coefficient of } \\
\text { consolidation } c_{v} \\
\left(\mathrm{~m}^{2} \cdot \mathrm{yr}^{-1}\right)\end{array}$ & $\begin{array}{c}\text { Hydraulic } \\
\text { permeability } \\
k\left(\mathrm{~m}^{2}\right)\end{array}$ & $\begin{array}{c}\text { Specific storage } \\
\mathrm{S}_{\mathrm{s}}\left(\mathrm{m}^{-1}\right)\end{array}$ & $\begin{array}{c}\text { Drained bulk } \\
\text { modulus } B \\
(\mathrm{MPa})\end{array}$ \\
\hline Mercia-1 [1] & 22.0 & 0.286 & $6.59 \times 10^{-10}$ & 52.93 & $2.09 \times 10^{-18}$ & $9.148 \times 10^{-6}$ & 1518 \\
\hline Mercia-1 [2] & 31.0 & 0.277 & $7.62 \times 10^{-10}$ & 26.38 & $1.20 \times 10^{-18}$ & $1.036 \times 10^{-5}$ & 1313 \\
\hline Mercia-1 [3] & 40.0 & 0.265 & $1.00 \times 10^{-9}$ & 18.27 & $1.09 \times 10^{-18}$ & $1.318 \times 10^{-5}$ & 1000 \\
\hline Mercia-1 [4] & 22.0 & 0.272 & $2.67 \times 10^{-10}$ & 52.74 & $8.43 \times 10^{-19}$ & $4.386 \times 10^{-6}$ & 3742 \\
\hline Mercia-1 [5] & 40.0 & 0.264 & $3.05 \times 10^{-10}$ & 28.33 & $5.17 \times 10^{-19}$ & $4.822 \times 10^{-6}$ & 3274 \\
\hline Mercia-1 [6] ${ }^{\#}$ & 49.0 & 0.252 & $1.08 \times 10^{-9}$ & 3.66 & $2.37 \times 10^{-19}$ & $1.415 \times 10^{-5}$ & 922 \\
\hline Mercia-1 [7] & 22.0 & 0.261 & $2.67 \times 10^{-10}$ & 34.26 & $5.47 \times 10^{-19}$ & $4.348 \times 10^{-5}$ & 3745 \\
\hline Mercia-1 [8] & 49.0 & 0.250 & $3.17 \times 10^{-10}$ & 46.75 & $8.85 \times 10^{-19}$ & $4.907 \times 10^{-6}$ & 3158 \\
\hline Mercia-1 [9] ${ }^{\#}$ & 58.0 & 0.241 & $7.85 \times 10^{-10}$ & 45.21 & $2.12 \times 10^{-18}$ & $1.051 \times 10^{-5}$ & 1274 \\
\hline Mercia-2 [1] & 22.0 & 0.293 & $4.90 \times 10^{-10}$ & 22.17 & $6.50 \times 10^{-19}$ & $7.146 \times 10^{-6}$ & 2039 \\
\hline Mercia-2 [2] & 31.0 & 0.287 & $5.22 \times 10^{-10}$ & 3.52 & $1.10 \times 10^{-19}$ & $7.506 \times 10^{-6}$ & 1916 \\
\hline Mercia-2 [3] ${ }^{\#}$ & 40.0 & 0.280 & $6.50 \times 10^{-10}$ & 7.53 & $2.93 \times 10^{-19}$ & $9.027 \times 10^{-6}$ & 1537 \\
\hline Mercia-2 [4] ${ }^{\#}$ & 49.0 & 0.271 & $7.64 \times 10^{-10}$ & 0.77 & $3.52 \times 10^{-20}$ & $1.036 \times 10^{-5}$ & 1309 \\
\hline Mercia-2 [5] ${ }^{\#}$ & 58.0 & 0.260 & $8.78 \times 10^{-10}$ & 7.86 & $4.13 \times 10^{-19}$ & $1.170 \times 10^{-5}$ & 1139 \\
\hline Mercia-3 [1] & 22.0 & 0.278 & $8.63 \times 10^{-10}$ & 4.20 & $2.17 \times 10^{-19}$ & $1.158 \times 10^{-5}$ & 1158 \\
\hline Mercia-3 [2] & 31.0 & 0.266 & $1.01 \times 10^{-9}$ & 4.83 & $2.92 \times 10^{-19}$ & $1.332 \times 10^{-5}$ & 989 \\
\hline Mercia-3 [3] & 40.0 & 0.254 & $1.02 \times 10^{-9}$ & 5.48 & $3.34 \times 10^{-19}$ & $1.338 \times 10^{-5}$ & 981 \\
\hline Mercia-3 [4] & 49.0 & 0.242 & $1.05 \times 10^{-9}$ & 0.59 & $3.71 \times 10^{-20}$ & $1.371 \times 10^{-5}$ & 952 \\
\hline Mercia-3 [5] & 58.0 & 0.234 & $6.78 \times 10^{-10}$ & 15.07 & $6.11 \times 10^{-19}$ & $9.197 \times 10^{-6}$ & 1476 \\
\hline Mercia-3 [6] & 67.0 & 0.222 & $1.06 \times 10^{-9}$ & 2.24 & $1.42 \times 10^{-19}$ & $1.379 \times 10^{-5}$ & 941 \\
\hline Mercia-3 [7] & 40.0 & 0.231 & $2.61 \times 10^{-10}$ & 0.54 & $8.42 \mathrm{E} \times 10^{-21}$ & $4.165 \times 10^{-6}$ & 3837 \\
\hline Mercia-3 [8] & 22.0 & 0.243 & $4.90 \times 10^{-10}$ & 1.86 & $5.45 \times 10^{-20}$ & $6.965 \times 10^{-6}$ & 2042 \\
\hline Mercia-3 [9] & 13.0 & 0.252 & $8.02 \times 10^{-10}$ & 0.44 & $2.11 \times 10^{-20}$ & $1.076 \times 10^{-5}$ & 1247 \\
\hline
\end{tabular}

Table 5 Consolidation data for tests Mercia-1 through -3 showing effective pressure, void ratio, coefficient of volume compressibility, hydraulic

permeability, specific storage (Equation 6) and drained bulk modulus. Pressure and temperature dependent values of water viscosity and density of $2.323 \times 10^{-3} \mathrm{~Pa} . \mathrm{s}$ and $1228 \mathrm{~kg} \cdot \mathrm{m}^{-3}$ respectively were used to calculate permeability (based on a $\mathrm{NaCl}$ solution with a molarity of $6.3 \mathrm{M}$ at $20^{\circ} \mathrm{C}$ and 0.1 $\mathrm{MPa}$ ). Values suffixed \# should be treated as indicative as outflow had not fully reached an asymptote by the end of the stage, Figure $5 \mathrm{~A}$. 


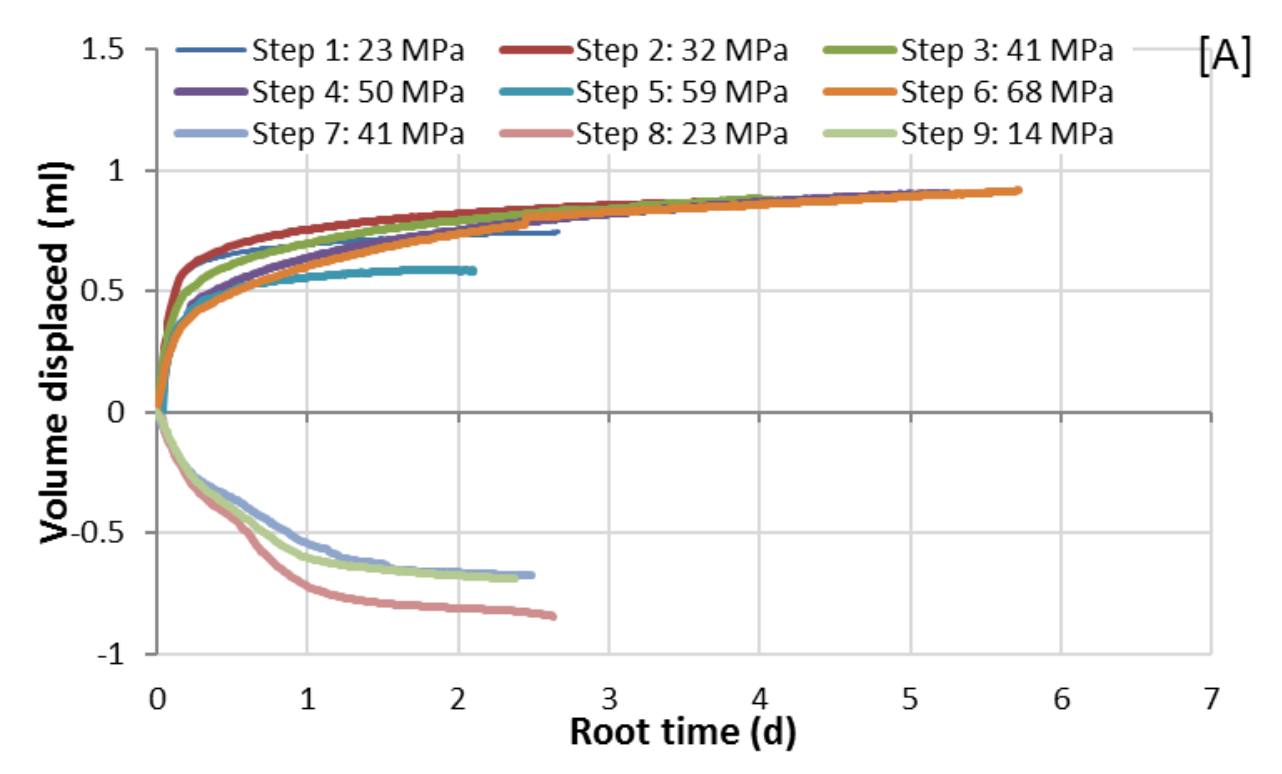

$[B]$

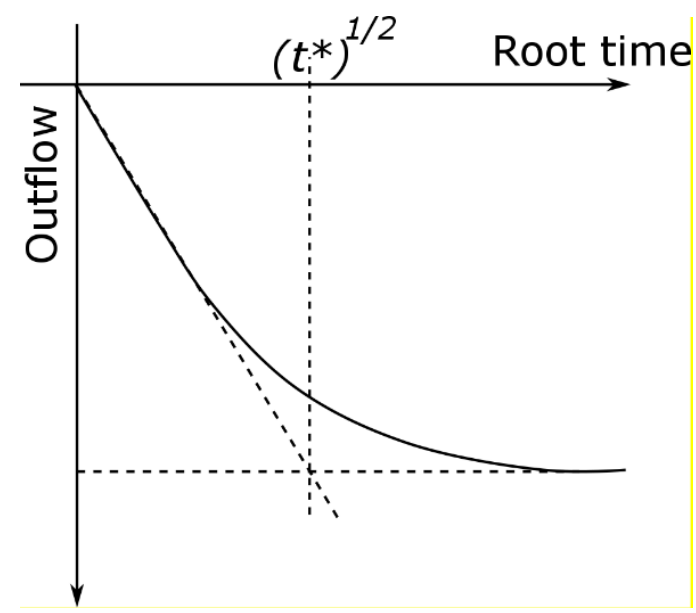

Figure 5. [A] Transient outflow data for test Mercia-3 showing volume displaced against root time in days. [B] Schematic technique used to derive the coefficient of consolidation.

\subsubsection{Sensitivity of specific storage, bulk modulus and hydraulic conductivity to pressure}

From Horseman et al. (1996), the specific storage of a material is given by;

$$
S_{s}=\rho_{w} g\left[\frac{1}{B}+\frac{\phi}{B_{w}}\right]
$$

Where $\rho_{w}$ is the pore-water density $\left[\mathrm{kg} / \mathrm{m}^{3}\right], g$ is the acceleration due to gravity $\left(=9.81 \mathrm{~m} / \mathrm{s}^{2}\right), B$ the drained bulk modulus (defined as $\left.1 / m_{v}\right)$ and $B_{w}(=2.2 \mathrm{GPa}$ ) is the bulk modulus of water. As such, specific storage therefore depends on two variables, the current porosity (or void ratio) and the bulk modulus (linking volume change to effective pressure). Figure 6 shows a weak correlation between the experimentally-determined values for specific storage and the applied effective pressure. The small increase in storage coefficient may be an artefact of the calculation approach related to increased deformation as the samples undergo yield and consolidation in the normally consolidated domain.

It is also possible to estimate the hydraulic conductivity, $K$, of the sample for a change in effective pressure, using the simple relationship 


$$
K=m_{v} c_{v} \gamma_{w}
$$

where $\gamma_{w}$ is the unit weight of water $\left(=9810 \mathrm{~N} \mathrm{~m}^{-3}\right)$. These values, along with those for specific storage are presented in Table 5.

Inspection of the permeability data indicates significant scatter, with no consistent pressure trends obvious in the data. Permeability values range from $\approx 2.1 \times 10^{-18}$ to $8.4 \times 10^{-21} \mathrm{~m}^{2}\left(2.1 \times 10^{-3}\right.$ to $8.5 \times 10^{-6}$ $\mathrm{mD}$ ), indicating a reasonably good capacity as a sealing formation, despite the higher values being somewhat more permeable than many caprocks. These values are comparable with those reported by Armitage et al. (2016), though extending to one order of magnitude lower. A number of possible explanations may account for this. Samples in this study were fully resaturated before testing, whereas in Armitage et al. (2016) specimens were oven-dried first. Whilst the samples were reported to be free from smectite, the response of the much lower-swelling illite and chlorite fractions cannot be discounted out of hand and may have been impacted by this process, though the reasonably well-cemented nature of the material may have acted to counter this effect somewhat. Alternatively, the use of a pulse decay method for measuring permeability may have resulted in an over-estimation of these values (Boulin et al., 2013; and Egermann et al., 2006). However, clearly the natural mineralogical variability within the MMG is a key control on these values and the more dolomitic horizons may potentially be of lower permeability as a result of cementation processes.

To examine the effect of pressure on hydraulic conductivity in more detail, a series of constant head tests at different effective pressures were undertaken on sample Mercia-3 (see section 3.3).

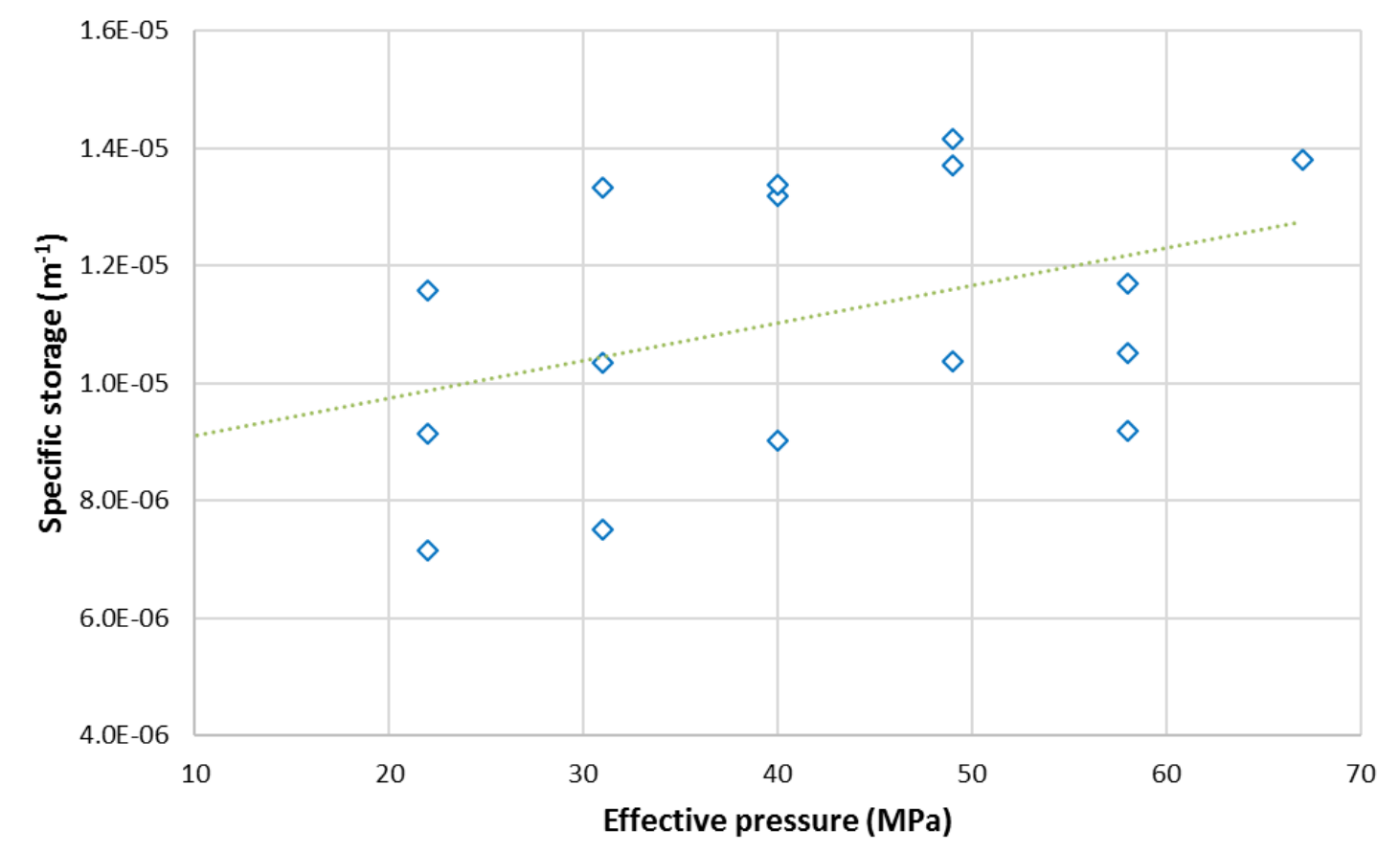

Figure 6. Specific storage plotted against effective pressure for incremental increases in confining pressure (excluding data from the RRL).

\subsection{Hydraulic behaviour}


Table 6 shows the hydraulic data obtained from a series of constant head tests performed on sample Mercia-3, Table 2. The methodology for analysis of the data is described in Appendix 1. Figure 7 shows permeability calculated from inflow and outflow data. The specimen exhibits an initial reduction in permeability as confining pressure increases. However, from an effective pressure of around $30 \mathrm{MPa}$, permeability values plateau and become insensitive to further increments in effective pressure. This suggests that while the bulk volume of the sample continues to decrease, flowing porosity appears to remain 'shielded' from the bulk reduction in porosity. This observation indicates flow within this sample of MMG is localised and not through the entire porosity of the material.

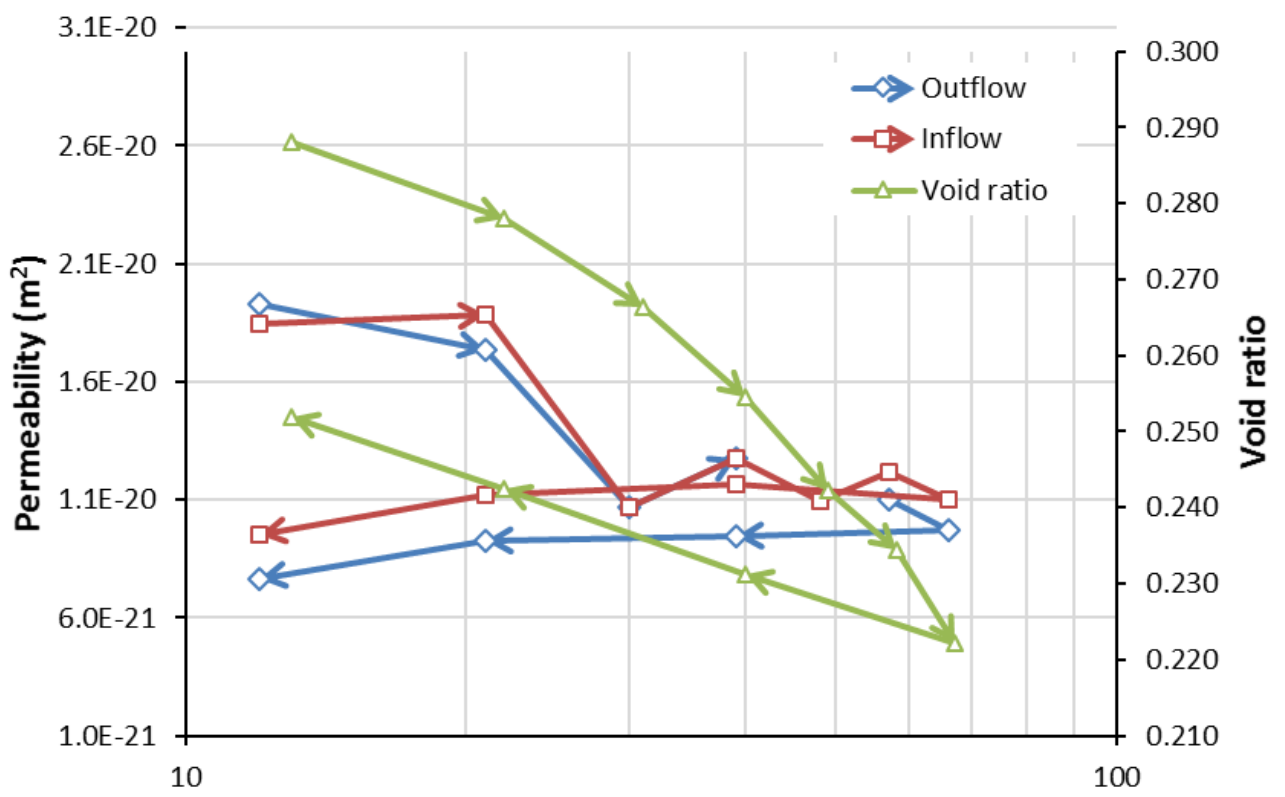

Average effective pressure (MPa)

Figure 7. Permeability values based on in- and outflow data for sample Mercia-3 plotted against average effective pressure. The offset in values for data on the RRL may relate to a small leak in the injection pump. The slight offset in points in pressure space between the void ratio and permeability stem from a correction to the effective pressure, accounting for the increase in porewater pressure at the injection face of the core.

\begin{tabular}{|c|c|c|c|c|}
\hline \multirow[t]{2}{*}{ Stage no. } & \multirow{2}{*}{$\begin{array}{c}\text { Average effective } \\
\text { pressure (MPa) }\end{array}$} & \multicolumn{3}{|c|}{ Permeability $\left(\mathrm{m}^{2}\right)$} \\
\hline & & Inflow & Outflow & Average \\
\hline Mercia-3 [0-B] & 12.0 & $1.85 \times 10^{-20}$ & $1.93 \times 10^{-20}$ & $1.89 \times 10^{-20}$ \\
\hline Mercia-3 [1-B] & 21.0 & $1.89 \times 10^{-20}$ & $1.74 \times 10^{-20}$ & $1.81 \times 10^{-20}$ \\
\hline Mercia-3 [2-B] & 30.0 & $1.07 \times 10^{-20}$ & $1.07 \times 10^{-20}$ & $1.07 \times 10^{-20}$ \\
\hline Mercia-3 [3-B] & 39.0 & $1.28 \times 10^{-20}$ & $1.28 \times 10^{-20}$ & $1.28 \times 10^{-20}$ \\
\hline Mercia-3 [4-B] & 48.0 & $1.10 \times 10^{-20}$ & - & $1.10 \times 10^{-20}$ \\
\hline Mercia-3 [5-B] & 57.0 & $1.22 \times 10^{-20}$ & $1.10 \times 10^{-20}$ & $1.16 \times 10^{-20}$ \\
\hline Mercia-3 [6-B] & 66.0 & $1.10 \times 10^{-20}$ & $9.71 \times 10^{-21}$ & $1.04 \times 10^{-20}$ \\
\hline Mercia-3 [7-B] & 39.0 & $1.16 \times 10^{-20}$ & $9.47 \times 10^{-21}$ & $1.05 \times 10^{-20}$ \\
\hline Mercia-3 [8-B] & 21.0 & $1.12 \times 10^{-20}$ & $9.26 \times 10^{-21}$ & $1.02 \times 10^{-20}$ \\
\hline Mercia-3 [9-B] & 12.0 & $9.52 \times 10^{-21}$ & $7.65 \times 10^{-21}$ & $8.58 \times 10^{-21}$ \\
\hline
\end{tabular}


Table 6. Hydraulic data for constant pressure tests performed on sample Mercia-3 showing stage number, effective pressure and permeability values based on inflow, outflow and average values.

\subsection{Numerical interpretation}

The fluid flow through a compressible porous medium is governed by the Biot's model (Biot 1941). In this model, the governing equation for flow is obtained by combining Darcy's law with the mass conservation equation, thus leading to

$$
\nabla \cdot\left(\frac{k}{\mu} \nabla p\right)=\phi \beta \frac{\partial p}{\partial t}+\frac{\partial}{\partial t}(\nabla \cdot \boldsymbol{u})
$$

where $\boldsymbol{u}$ is the solid displacement [m], $p$ is the fluid pressure [Pa], $k$ is the intrinsic permeability $\left[\mathrm{m}^{2}\right]$, $\mu$ is the dynamic viscosity of the fluid [Pa's], $\phi$ is the porosity [-] and $\beta$ is the compressibility of the fluid $\left[\mathrm{Pa}^{-1}\right]$. Note that an isotropic permeability, represented by the scalar $k$, is assumed here.

The classical Biot's model assumes an elastic deformation of the matrix. Thus, Equation (8) is coupled to the mechanical equilibrium equation

$$
\nabla \cdot \boldsymbol{\tau}+\boldsymbol{f}=\mathbf{0}
$$

where $\boldsymbol{f}$ is the body force per unit volume of the medium $\left[\mathrm{N} / \mathrm{m}^{2}\right]$ and $\boldsymbol{\tau}$ is the total stress on the medium $[\mathrm{Pa}]$, which can be expressed as

$$
\boldsymbol{\tau}=\boldsymbol{p}^{\prime}-\alpha p \mathbf{I}
$$

where $\boldsymbol{p}^{\prime}$ is the effective stress (or pressure) tensor [Pa], $\alpha$ is the Biot's coefficient [-] and $\mathrm{I}$ is the identity tensor. Under the assumption of small strains and assuming an isotropic linear elastic material, the effective stress tensor takes the form

$$
\boldsymbol{p}^{\prime}=\lambda \operatorname{tr}(\boldsymbol{\varepsilon}) \mathbf{I}+2 G \boldsymbol{\varepsilon}
$$

where $\lambda$ is the first Lamé's constant [Pa], $G$ is the shear modulus [Pa] and $t r$ stands for the trace operator. For the sake of simplicity, $\alpha=1$ is here assumed. This is a reasonable assumption for a saturated porous medium and leads to the equation

$$
\frac{E}{2(1+v)(1-2 v)} \nabla(\nabla \cdot \boldsymbol{u})+\frac{E}{2(1+v)} \nabla^{2} \boldsymbol{u}-\nabla p=-\boldsymbol{f}
$$

where $E$ is the Young's modulus [Pa] and $v$ is the Poisson's coefficient [-]. Note that the relationships $\boldsymbol{\varepsilon}=\nabla^{s} \boldsymbol{u}, \lambda=\frac{E v}{(1+v)(1-2 v)}$ and $G=\frac{E}{2(1+v)}$ have here been used.

In order to estimate the values of the permeability $k$ and the Young's Modulus $E$ of the three MMG samples, the coupled system formed by Equations (8) and (12) is here numerically solved. Following standard procedures, these equations are discretized in space using the finite element method and in time using the finite difference method. Due to the nature of the problem, a two-dimensional 
axisymmetric finite element model is here used, see Figure 8. Regarding the time discretization, the backward Euler scheme is here employed.

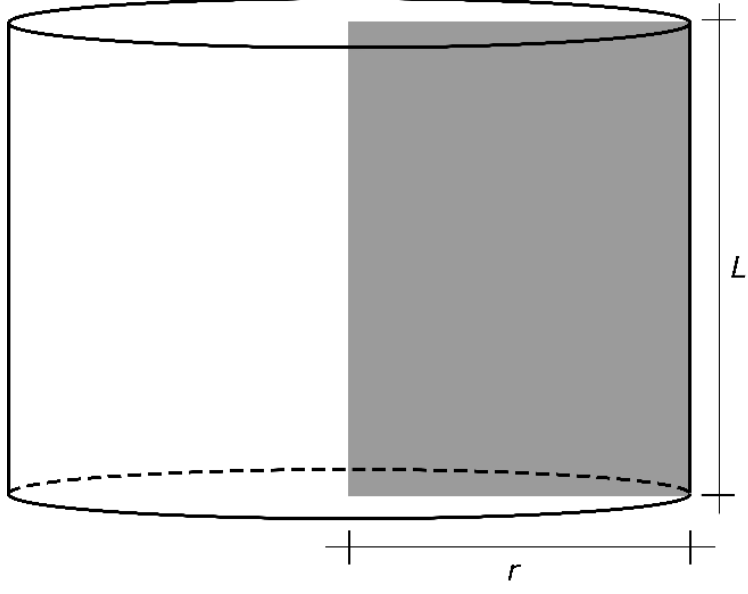

[A]

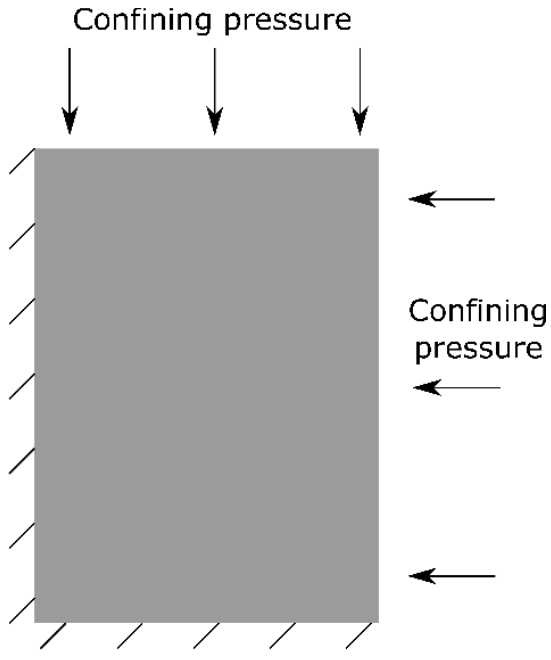

[B]

Figure 8. Schematic diagram of the main elements of $[A]$ the axisymmetric plane for the numerical calculations and $[\mathrm{B}]$ the prescribed boundary conditions.

The fitting procedure consists of several steps:

1. The two-dimensional finite element meshes are first generated. Here, uniform meshes of 50x50 elements are employed. The geometric parameters are summarised in Table 7.

2. The fixed material parameters describing Equations (8) and (12) are defined.

- As reported by Hobbs et al. (2002), reported values for the Poisson's ratios of the MMG vary from 0.2 and 0.4 . Hence, an intermediate value $v=0.25$ is considered here for all the numerical simulations.

- A fixed dynamic viscosity of water $2.32 \times 10^{-3} \mathrm{~Pa} \cdot \mathrm{s}$ is also assumed.

- As usual, the fluid storage coefficient $\phi \beta$ is here defined by using its relation with the specific storage $\left[\mathrm{m}^{-1}\right]$

$$
S_{S}=\rho_{w} g(\alpha+\phi \beta)
$$

where $\rho_{w}$ is the porewater density $\left[\mathrm{kg} / \mathrm{m}^{3}\right], g$ is the gravitational acceleration ( $=9.81$ $\left.\mathrm{m} / \mathrm{s}^{2}\right)$ and $\alpha$ is the solid-phase compressibility $\left[\mathrm{Pa}^{-1}\right]$.

For the sake of simplicity, this fluid storage coefficient $\phi \beta$ is considered to be constant in each MMG sample and obtained after the first consolidation stage by using the experimental specific storage and

$$
\alpha=3 \frac{1-2 v}{E}
$$

As seen in Table 7, the sample-dependent fluid storage coefficients obtained by means of this technique differ from the theoretical value $\phi \beta=0.207 \cdot \frac{1}{2.2 \times 10^{9}}=9.41 \times 10^{-11}$ by factors 
of 4.19 (sample 1), 3.15 (sample 2) and 4.24 (sample 3). These slight differences lead to negligible impact in terms of fitted permeability and fitted Young's modulus. Both techniques to derive the fluid storage coefficient could, therefore, have been employed.

3. Initial values $E_{0}, k_{0}$ for the two fitting parameters are then considered. The Young's modulus is iteratively updated in such a way to minimise the difference between the numerical outflow and the measured one whereas the permeability value is iteratively updated to minimise the differences between the numerical and experimental transient phases of the time versus outflow curves.

\begin{tabular}{|c|c|c|c|c|}
\hline \multirow{2}{*}{ Meaning } & \multirow{2}{*}{$\begin{array}{c}\text { Symbol } \\
{[\text { units] }}\end{array}$} & Sample 1 & Sample 2 & Sample 3 \\
\cline { 3 - 5 } & $r[\mathrm{~mm}]$ & 26.84 & 27.21 & 24.98 \\
\hline Radius of the sample & $L[\mathrm{~mm}]$ & 36.81 & 38.77 & 48.76 \\
\hline Length of the sample & $v[-]$ & & \multicolumn{3}{|c|}{$2.32 \times 10^{-3}$} \\
\hline Poisson's coefficient & $\mu\left[\mathrm{Pa}^{2} \mathrm{~s}\right]$ & & \multicolumn{3}{|c|}{} \\
\hline Dynamic viscosity & $\phi \beta\left[\mathrm{Pa}^{-1}\right]$ & $3.94 \times 10^{-10}$ & $2.96 \times 10^{-10}$ & $3.99 \times 10^{-10}$ \\
\hline Fluid storage coefficient & & \multicolumn{3}{|c}{} \\
\hline
\end{tabular}

Table 7. Geometrical and material parameters used in the numerical fittings.

As shown by Horseman et al. (2005), the linear elastic model is unable to represent multiple testing stages from a single set of material values. Thus, we decided to treat each consolidation stage as separate tests and the previous numerical procedure was used to fit $E$ and $k$ at each stage. The results of this fitting approach are shown in Figure 9 through Figure 11 and the parameter values obtained for each consolidation test and each stage are listed in Table 8 to Table 10. 

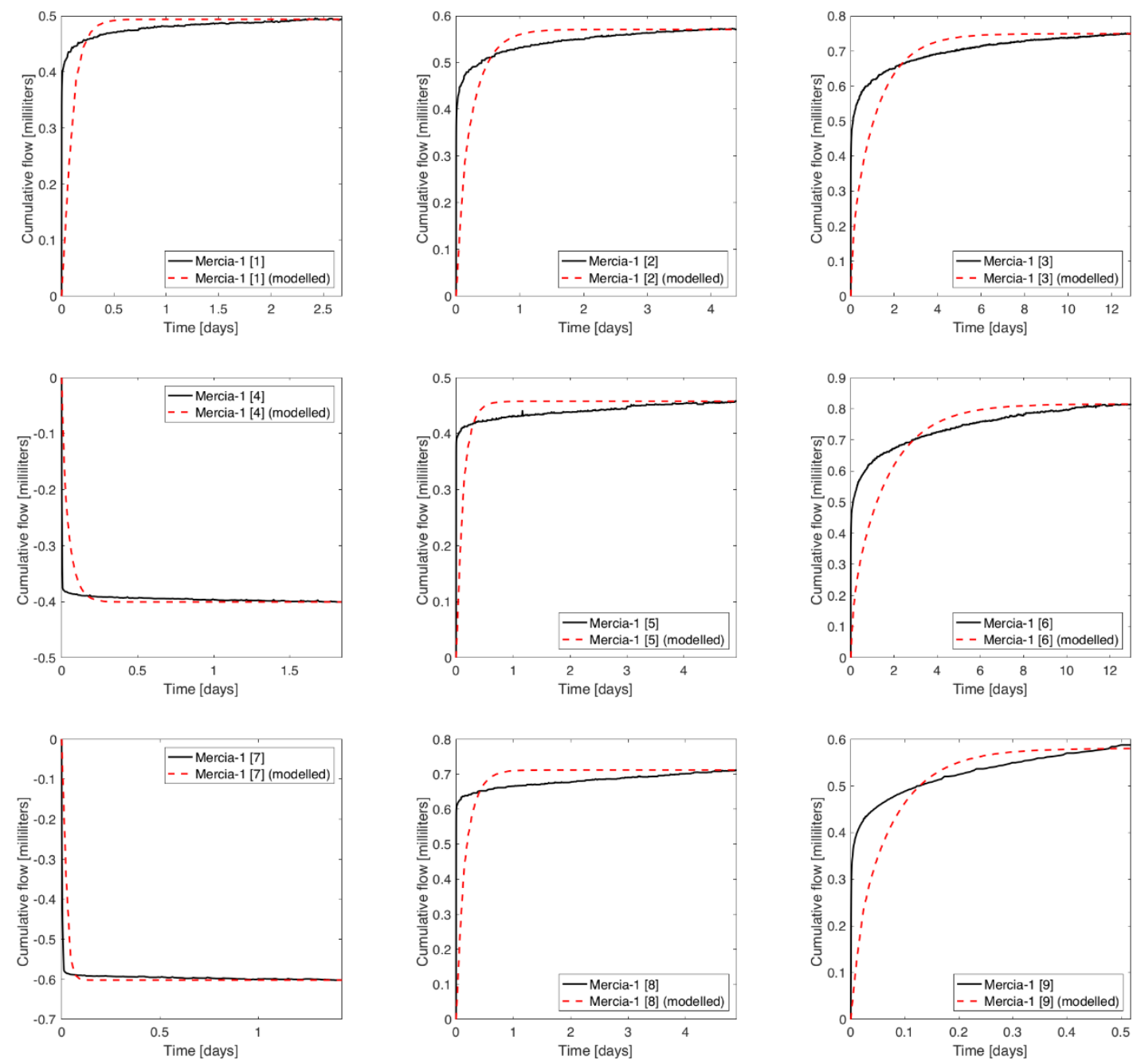

Figure 9. Comparison of model to flow data for the Mercia-1 sample. 

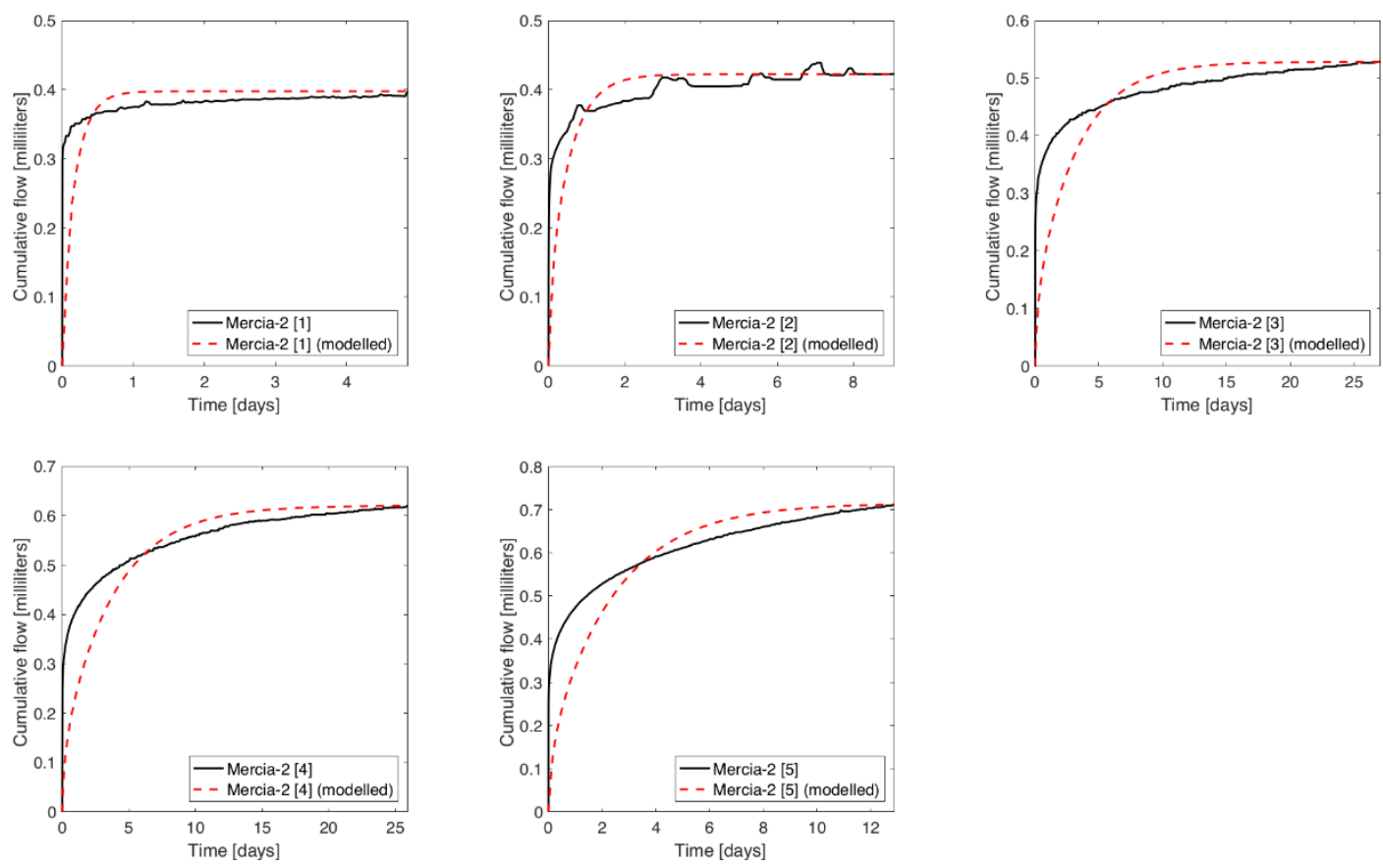

Figure 10. Comparison of model to flow data for the Mercia-2 sample. 

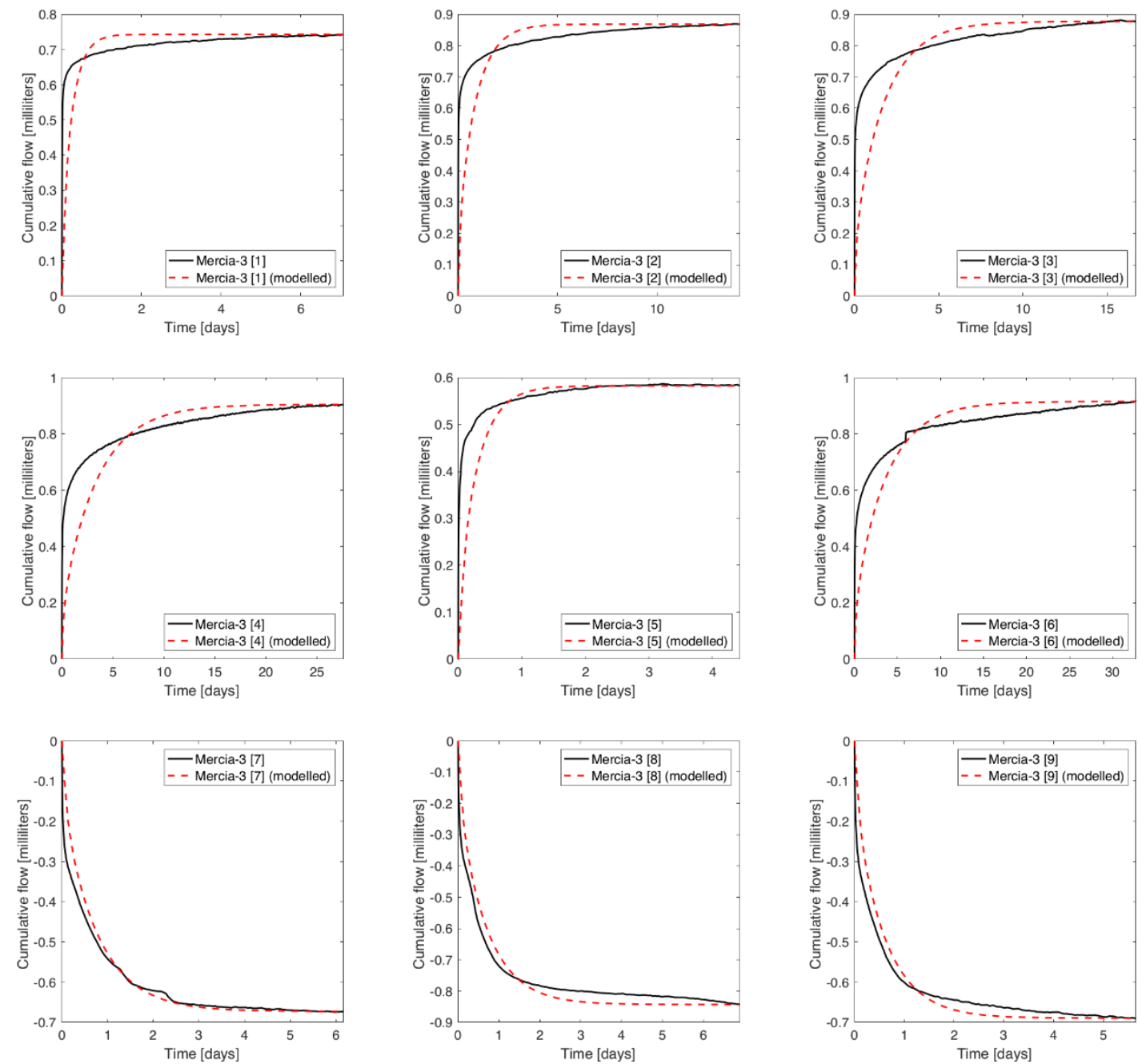

Figure 11. Comparison of model to flow data for the Mercia-3 sample. 


\begin{tabular}{|c|c|c|c|c|}
\hline \multicolumn{5}{|c|}{ Mercia-1 } \\
\hline \multirow[b]{2}{*}{ Consolidation stage } & \multicolumn{2}{|c|}{ Experimental } & \multicolumn{2}{|c|}{ Fitted } \\
\hline & $\begin{array}{l}\text { Permeability } \\
\qquad\left[\mathrm{m}^{2}\right]\end{array}$ & $\begin{array}{c}\text { Young's } \\
\text { Modulus } \\
\text { [GPa] }\end{array}$ & $\begin{array}{c}\text { Permeability } \\
\left.\qquad \mathrm{m}^{2}\right]\end{array}$ & $\begin{array}{c}\text { Young's } \\
\text { Modulus } \\
\text { [GPa] }\end{array}$ \\
\hline 1: from 14 to $23 \mathrm{MPa}$ & -- & 3.057 & $2.22 \times 10^{-19}$ & 2.880 \\
\hline 2: from 23 to $32 \mathrm{MPa}$ & -- & 2.486 & $6.73 \times 10^{-20}$ & 2.233 \\
\hline 3: from 32 to $41 \mathrm{MPa}$ & -- & 1.857 & $1.68 \times 10^{-20}$ & 1.561 \\
\hline 4: from 41 to $23 \mathrm{MPa}$ & -- & 4.080 & $2.08 \times 10^{-19}$ & 6.305 \\
\hline 5: from 23 to $41 \mathrm{MPa}$ & -- & 5.955 & $9.68 \times 10^{-20}$ & 5.974 \\
\hline 6: from 41 to $50 \mathrm{MPa}$ & -- & 1.671 & $1.29 \times 10^{-20}$ & 1.419 \\
\hline 7: from 50 to $23 \mathrm{MPa}$ & -- & 3.706 & $1.20 \times 10^{-18}$ & 7.610 \\
\hline 8: from 23 to $50 \mathrm{MPa}$ & -- & 6.247 & $6.60 \times 10^{-20}$ & 5.564 \\
\hline 9: from 50 to $59 \mathrm{MPa}$ & -- & 2.215 & $2.40 \times 10^{-19}$ & 2.2120 \\
\hline
\end{tabular}

Table 8. Parameter values determined for each stage of consolidation test 1.

\begin{tabular}{|c|c|c|c|c|}
\hline \multirow{2}{*}{ Consolidation stage } & \multicolumn{2}{|c|}{ Experimental } & \multicolumn{2}{c|}{ Fitted } \\
\cline { 2 - 5 } & $\begin{array}{c}\text { Permeability } \\
{\left[\mathrm{m}^{2}\right]}\end{array}$ & $\begin{array}{c}\text { Young's } \\
\text { Modulus } \\
{[\mathrm{GPa}]}\end{array}$ & $\begin{array}{c}\text { Permeability } \\
\left.\text { [m }{ }^{2}\right]\end{array}$ & $\begin{array}{c}\text { Young's } \\
\text { Modulus } \\
\text { [GPa] }\end{array}$ \\
\hline 1: from 14 to 23 MPa & $2.01 \times 10^{-17}$ & 3.937 & $7.55 \times 10^{-20}$ & 3.582 \\
\hline 2: from 23 to 32 MPa & $1.56 \times 10^{-17}$ & 3.472 & $2.49 \times 10^{-20}$ & 3.112 \\
\hline 3: from 32 to 41 MPa & $1.09 \times 10^{-17}$ & 2.758 & $4.76 \times 10^{-21}$ & 2.358 \\
\hline 4: from 41 to 50 MPa & $8.81 \times 10^{-18}$ & 2.326 & $4.57 \times 10^{-21}$ & 1.976 \\
\hline 5: from 50 to 59 MPa & -- & 2.007 & $7.83 \times 10^{-21}$ & 1.732 \\
\hline
\end{tabular}

Table 9. Parameter values determined for each stage of consolidation test 2. 


\begin{tabular}{|c|c|c|c|c|}
\hline \multicolumn{5}{|c|}{ Mercia-3 } \\
\hline \multirow[b]{2}{*}{ Consolidation stage } & \multicolumn{2}{|c|}{ Experimental } & \multicolumn{2}{|c|}{ Fitted } \\
\hline & $\begin{array}{l}\text { Permeability } \\
\left.\qquad \mathrm{m}^{2}\right]\end{array}$ & $\begin{array}{c}\text { Young's } \\
\text { Modulus } \\
\text { [GPa] }\end{array}$ & $\begin{array}{c}\text { Permeability } \\
{\left[\mathrm{m}^{2}\right]}\end{array}$ & $\begin{array}{c}\text { Young's } \\
\text { Modulus } \\
\text { [GPa] }\end{array}$ \\
\hline 1: from 14 to $23 \mathrm{MPa}$ & $1.94 \times 10^{-20}$ & 2.312 & $1.32 \times 10^{-19}$ & 1.975 \\
\hline 2: from 23 to $32 \mathrm{MPa}$ & $1.74 \times 10^{-20}$ & 1.858 & $4.20 \times 10^{-20}$ & 1.567 \\
\hline 3: from 32 to $41 \mathrm{MPa}$ & $1.07 \times 10^{-20}$ & 1.766 & $2.05 \times 10^{-20}$ & 1.511 \\
\hline 4: from 41 to $50 \mathrm{MPa}$ & $1.28 \times 10^{-20}$ & 1.671 & $1.08 \times 10^{-20}$ & 1.440 \\
\hline 5: from 50 to $59 \mathrm{MPa}$ & $1.16 \times 10^{-20}$ & 2.432 & $9.63 \times 10^{-20}$ & 2.489 \\
\hline 6: from 59 to $68 \mathrm{MPa}$ & $1.10 \times 10^{-20}$ & 1.594 & $1.03 \times 10^{-20}$ & 1.422 \\
\hline 7: from 68 to $41 \mathrm{MPa}$ & $9.72 \times 10^{-21}$ & 4.043 & $2.26 \times 10^{-20}$ & 6.107 \\
\hline 8: from 41 to $23 \mathrm{MPa}$ & $9.47 \times 10^{-21}$ & 2.288 & $3.33 \times 10^{-20}$ & 3.263 \\
\hline 9: from 23 to $14 \mathrm{MPa}$ & $8.78 \times 10^{-21}$ & 1.525 & $5.13 \times 10^{-20}$ & 2.009 \\
\hline
\end{tabular}

Table 10. Parameter values determined for each stage of consolidation test 3.

As shown in Figure 9 through Figure 11, Biot's model provides reasonable theoretical flow-time curves. As seen in Figure 12 (first row), the theoretical Young's moduli are in good agreement with the experimental results, especially in those cases where the confining stress increases. For those experimental tests where permeability measurements were available, the model yielded similar results for the third consolidation test whereas differences of three orders of magnitude were detected in the second sample, see Figure 12 (second row). These differences are of only one order of magnitude when compared with the ones obtained by Taylor's method (instead of direct measurements). This discrepancy might be due to the fact that Biot's model does not account for the small-scale heterogeneity and its consequent localisation of flow. Thus, for this consolidation test, the numerical values should be considered as indicative only. Although not crucial for this analysis, observations from the tests highlight the need for a more complex rock deformation model to include a creep effect. Such behaviour is outside the scope of this work and deserves a greater understanding in future contributions. 

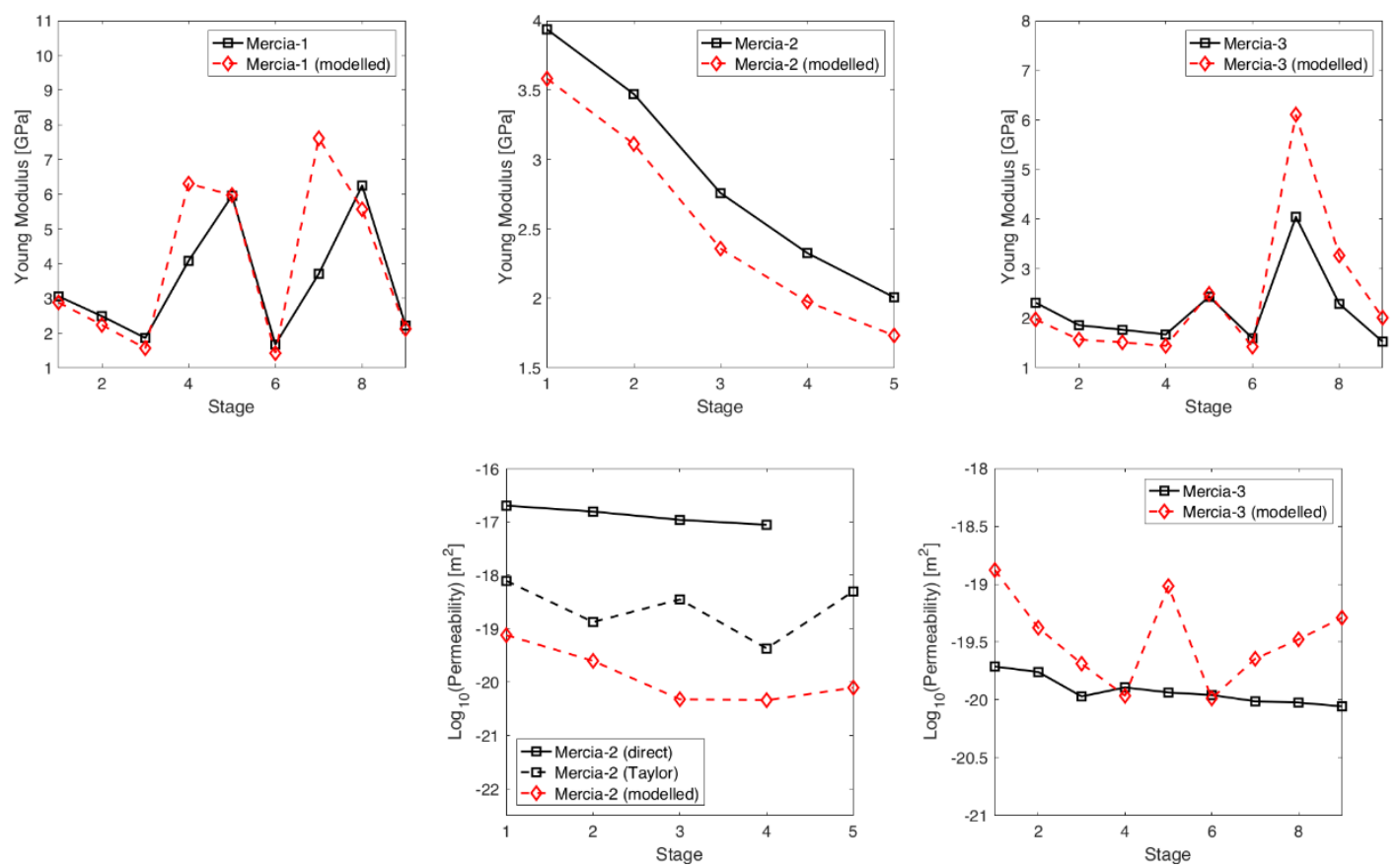

Figure 12. Experimental versus theoretical Young's modulus (first row) and permeability (second row).

\section{Discussion}

Figure 12. Experimental versus theoretical Young's modulus (first row) and permeability (second row).

To assess the impact of depletion and re-inflation, it is first necessary to describe the volume change behaviour of the caprock as a function of the prevailing stress state. Critical state theory, proposed by Roscoe et al. (1958), provides such a framework by linking volume change of a material to both effective stress (or pressure), $p^{\prime}$, and differential stress, $q^{\prime}$. Here, the onset of permanent deformation (yield) occurs in an isotropic medium at a critical specific void ratio, $e_{c}$, and a critical specific volume:

$$
v_{c}=1+e_{c}
$$

Yield is considered to occur as a combination of effective stress and specific volume, coinciding with a state boundary surface. Experimentation has shown that, when sheared, a deforming material will tend towards criticality, a state where large shear distortions will occur without any further changes in $p^{\prime}, q^{\prime}$ or $v$ (Schofield and Wroth, 1968). The Critical State Line (CSL) is the locus of all possible critical states in $p^{\prime}-q^{\prime}-v$ space. In critical state soil mechanics (CSSM), the change of state of a medium can be represented by its progression along a given stress path, allowing deformation history of the material to be described, as well as its current state.

The yield surface can be described in terms of the no-tension cut-off surface, the Hvorslev surface and the Roscoe surface (Figure 3B). Conventionally, in $p^{\prime}-q^{\prime}$ space, the former is defined as the transition from compressional to tensional deformation, occurring at:

$$
q^{\prime}=3 p^{\prime}
$$


Heavily overconsolidated sediments or those which have been unloaded by either increasing pore pressure or total stress reduction, deform along the Hvorslev surface (Hvorslev, 1937), which is described as

$$
q^{\prime}=H p^{\prime}+(M-H) \exp \left(\frac{\Gamma-v_{f}}{\lambda}\right)
$$

where $H$ and $\mathrm{M}$ are intrinsic material properties, $-\lambda$ is the slope of the $\mathrm{VCL}$ in the $v-p^{\prime}$ space and $\Gamma$ is the specific volume intercept of the CSL at a reference pressure $p_{r}^{\prime}$. For a porous rock, this region of $p^{\prime}-q^{\prime}$ space is associated with deformation by shear localisation and dilatancy.

Finally, the Roscoe surface is defined as the state boundary along which normally consolidated sediments deform and can be described by

$$
q^{\prime}=M p^{\prime}\left(\frac{p_{c}^{\prime}}{p^{\prime}}-1\right)^{0.5}
$$

where $p_{c}^{\prime}$ is the preconsolidation pressure of the clay. For a porous material, this region of $p^{\prime}-q^{\prime}$ space is associated with shear-enhanced compaction/cataclasis resulting in compactive strain.

In the $p^{\prime}-q^{\prime}$ space, the projection of the CSL (Figure 3B) can be defined as

$$
q^{\prime}=M p^{\prime}
$$

and meets the Roscoe surface at its maximum value (Figure 3B).

However, in lithified materials, such as sandstone or shale, it is possible for failure to occur above the hypothetical Hvorslev surface and modification of the yield surface is required to allow for the influence of tensile strength (Shah, 1997). In such cases, the Hvorslev surface may be considered to represent residual strength of the material. Wong et al. (1997) showed that an elliptical model was sufficient to represent the yield behaviour of sands and sandstone, where the maximum effective pressure at yield is known as the grain-crushing pressure, $p^{*}$, on hydrostatic loading, equivalent to the pre-consolidation pressure $p_{c}^{\prime}$ described above.

Sheldon et al. (2006) found a modified version of this criterion provided an improved fit to experimental sandstone data-sets. In this case, the yield surface was described differently above and below the effective pressure at the critical state point, $p_{c r}^{\prime}$, such that:

$$
\left(q^{\prime}\right)^{2}-\frac{q^{\prime} p^{*} M}{2}\left[1-\left(\frac{p^{\prime}}{p_{c r}^{\prime}}-1\right)^{2}\right]=0 \quad \text { for } p^{\prime} \leq p_{c r}^{\prime}
$$

And

$$
\left(q^{\prime}\right)^{2}-\left(\frac{M p^{*}}{2}\right)^{2}\left[1-\left(\frac{p^{\prime}-p_{c r}^{\prime}}{p^{*}-p_{c r}^{\prime}}\right)^{2}\right]=0 \quad \text { for } p^{\prime} \geq p_{c r}^{\prime}
$$

where

$$
p_{c r}^{\prime}=\beta p^{*}
$$

and $\beta$ is a material constant, generally ranging between 0.45 and 0.5 . 
Unfortunately, there is a paucity of experimental data delineating the form of the yield curve for caprock materials, especially under drained conditions. Horseman et al. (1993) directly measured the critical state friction parameter for drained Boom Clay, a lightly overconsolidated, Tertiary sediment from Belgium, as $M=0.81$. In contrast, a large resource of data is available to parameterise the critical state envelope in sandstones (Wong et al, 1997; Zhu and Wong, 1997; Cuss et al., 2003; Sheldon et al., 2006; Khan et al., 1991). In these studies, $M$ is generally seen to fall in the range of 1-1.5 and $\beta$ varies between 0.45 and 0.55 .

In this study, the envelope form described by Sheldon et al. (2006) (Equations 20 and 21) was applied in order to estimate the critical state behaviour of the test material , for two primary reasons: (i) the competent/well-lithified nature of the samples and (ii) the reduced number of uncertain parameters. As such, critical state yield envelopes could be plotted for each test sample by taking the measured preconsolidation pressure as equivalent to grain crushing pressure and by considering a likely range of values for $\mathrm{M}$, between 0.81 and 1.0 (assuming the MMG is likely to fall between values for a lightly overconsolidated clay and a sandstone), and $\beta$, between $0.45-0.55$ (Figure 13A).

The resulting yield envelopes provide a tool with which to assess the mechanical response of the test material to a depletion history scenario. A scenario assuming a reduction in pore pressure of $10 \mathrm{MPa}$ was selected. Initial stress conditions were calculated for depths of $1 \mathrm{~km}, 1.3 \mathrm{~km}$ and $1.6 \mathrm{~km}$, assuming a linear stress gradient for the maximum and minimum principal stresses, $\sigma_{1}$ and $\sigma_{3}$ respectively, following those as assumed by Williams et al. (2014) for the southern North Sea Triassic. An initial formation pressure (prior to depletion) of $1 \mathrm{MPa}$ above hydrostatic pressure was asssumed. For all yield envelopes, $p^{\prime}$ was taken as the effective mean stress, equal to $\frac{1}{3}\left(\sigma_{1}+2 \sigma_{3}\right)-$ $p_{p}$, where $p_{p}$ is the porewater pressure.

The resulting change in differential stress is less well constrained. Zoback (2010) describes the relationship between $p^{\prime}$ and $q^{\prime}$, for a chosen stress path, as:

$$
q^{\prime} \sim j \Delta p^{\prime}
$$

where $j$ is a constant equal to $\frac{2}{3}$. However, Ruistuen et al. (1999) highlight that during depletion the influence of pore pressure on differential stress is variable, citing examples where $j$ varies between 0.1 and 1.0 and manifest as shallower or steeper stress paths in $p^{\prime}-q^{\prime}$ space, respectively.

For the purposes of this study, a potential range of depletion stress paths were considered. These are shown for the test samples with the highest and lowest measured preconsolidation pressures, Mercia2 (Figure 13B) and Mercia-3 (Figure 13D). Three triangles are used to denote the three initial pressure condition scenarios (at depths, $z=1 \mathrm{~km}, 1.3 \mathrm{~km}$ and $1.6 \mathrm{~km}$ ). The steeper and shallower slopes of these triangles represent stress paths for $j=0.1$ and 1.0 , respectively. The impacts of uncertainty in $M$ and $\beta$ on the yield envelope is reflected by the shaded area.

During depletion, a $10 \mathrm{MPa}$ reduction in pore pressure will result in increasing effective and differential stresses, moving the reservoir and caprock interface towards the wet-side of the yield envelope. Figures 13B and 13D highlight the potential for yield to occur under a range of scenarios. Allowing for variability in $M$ and $\beta$, yield seems likely for Mercia-3, more especially at higher values of 
$j$, although it may also occur at low values of $j$, at greater depths. Yield is less likely to occur for Mercia2 , though again the likelihood is increased at greater depths and higher values of $j$.

Yield will result in permanent deformation, but the form of this will be dependent on where the stress path experienced intersects the envelope. Of importance is the position of the critical stress point, which exists at the peak of the yield curve. Deformation to the left of this point is associated with dilation ('dry-side' behaviour) and permeability enhancement (though reduction may also occur), whilst compaction ('wet-side' behaviour) and permeability reduction is always expected to the right (Sheldon et al., 2006). Inspection of Figure 13D indicates that wet-side deformation is predicted in the majority of cases, suggesting that, in the absence of subsidence-induced shear, detrimental effects on caprock sealing are not expected as a result.

However, for Mercia-3 in general (Figure 13B) and Mercia-2 at shallower depths and greater values of $j$, intersection close to the critical point or on the dry-side is also observed. In such instances, potential for permeability enhancement cannot be discounted. It is important to note the controlling influence of initial stress conditions on this behaviour, especially given the potential for formations to recover a significant degree of their original pore fluid pressure after production ends, for example due to aquifer encroachment. Whilst yield may be more likely to occur in caprocks beginning at higher stress conditions, those scenarios involving a greater initial effective pressure are more likely to lead to wetside deformation and permeability reduction. Conversely, in lower effective stress conditions, the potential for permeability enhancement is increased. Awareness of this sensitivity may allow the selection of CCS sites where caprock permeability is less likely to have been impacted by previous depletion activities.

It should be noted that this analysis relates specifically to the samples tested and the primary influencing factor will be the burial history and resulting preconsolidation pressure of the caprock in question. The more overconsolidated, the less likely it will be that yield is reached during depletion. However, if yield does occur, the likelihood of dilatant deformation and permeability enhancement is increased. It is also interesting that three samples taken from the same depth interval show a reasonably large variation in their measured preconsolidation pressures, much greater than uncertainty in the methodology applied $( \pm 1 \mathrm{MPa}$ ) despite having the same burial history in common. This demonstrates the importance of lithological variability, which may also be impacted by diagenetic changes. Such variability has the potential to significantly alter caprock response and may be the difference between yield occurring or not. However, further examination of the influence of lithological variability on mechanical response is required to test the degree to which this may impact caprock behaviour.

In cases where yield on depletion occurs, inelastic deformation will also impact the return stress path on injection of carbon dioxide (Figure 13C). The initial stress path will be followed (1) until the yield envelope is intersected (2). At this stage, stress levels above the yield surface cannot occur and begin to converge towards the critical state point. However, as shown during consolidation testing, yield will result in a reduction in the void ratio, reflected as a migration along the third axis of the critical state envelope, the specific volume (Figure $3 C$ ). In $p^{\prime}-q^{\prime}$ space this will be manifest as an increase in the size of the critical state envelope (3; Figure 13C), as the rock responds to the changing stress conditions. The amount of deformation experienced during this stage will be dependent on the slope of the envelope in $q^{\prime}-v$ space, as well as the total reduction in pore pressure 
allowed during this phase, and will control the degree of hysteresis experienced when pore pressure again increases during injection of $\mathrm{CO}_{2}$. Any hysteresis will lead to a greater chance of intersecting the dry-side of the envelope as pore pressures are elevated to their original values. Also of importance will be the drainage condition of the caprock during these changes, which will impact the stress path slope between stages (2) and (3). Undrained conditions are more likely to lead to dryside behaviour, whilst improved drainage will encourage wet-side deformation. The full draw down experienced by the reservoir will primarily impact on the caprock at the interface with the reservoir, whilst propagation into the caprock will be limited by its transport characteristics. As such, the impact of stress path changes will be dependent on the thickness of the seal and its initial permeability.

However, further work is required to experimentally verify this basic analysis, allowing for the influence of differential stress in post-yield scenarios, as well as widening the critical state parameter data-set for caprocks. In addition, an examination of the degree of and controls on hysteresis would be beneficial when assessing the geomechanical impact of stress changes during $\mathrm{CO}_{2}$ injection.
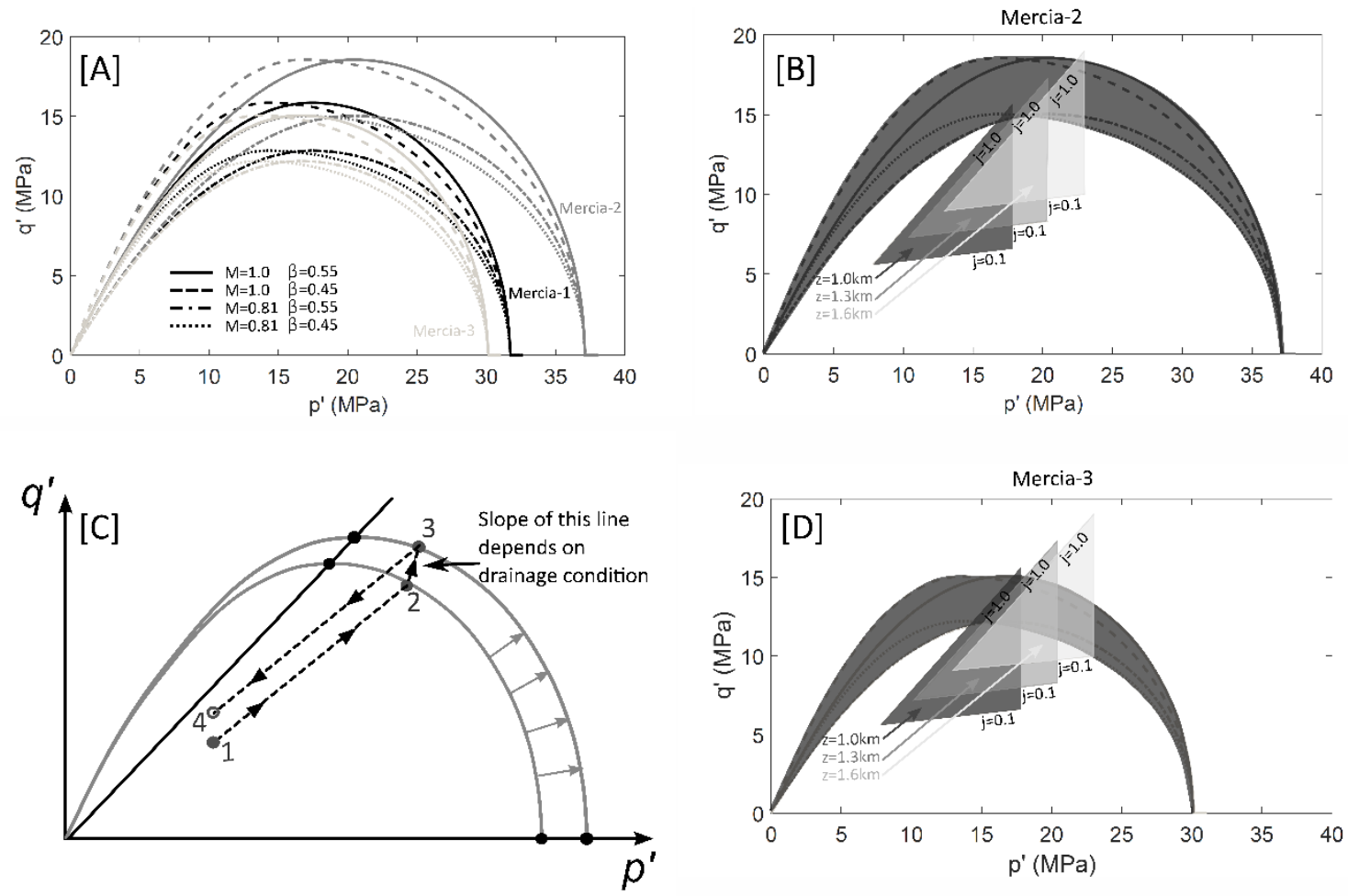

Figure 13. Critical state envelopes in $\boldsymbol{p}^{\prime}-\boldsymbol{q}^{\prime}$ (effective-differential stress) space, A.) for MMG samples (Mercia 1 to 3 ). Uncertainty in the form of the critical state parameters is reflected by varying values for $M$ and $\beta$. B.) Stress path scenarios for Mercia-2. Uncertainty in the position of the yield envelope is shaded in grey. Three shaded triangles highlight a range of potential stress path scenarios during depletion for three selected depths. The slope of the stress path is varied from 1.0 to 0.1 to reflect the sensitivity of differential stress to a reduction in pore pressure. Yield is predicted to occur when a stress path intersects the yield envelope. C.) A schematic highlighting the stress path taken during (1-2) depletion pre-yield, (2-3) depletion post-yield, (3-4) pore pressure recovering resulting from injection of $\mathrm{CO}_{2}$. The envelope will grow in response to yield. 


\section{Conclusions}

A sound understanding of the hydromechanical behaviour of caprock material is advantageous when assessing its response to changing stress conditions (e.g., during depletion or injection of $\mathrm{CO}_{2}$ ). Results presented in this study demonstrate the influence of effective pressure on physical properties of Mercia Mudstone Group samples from the Larne Basin, Northern Ireland. The form of the consolidation response of the material appears reasonably consistent, despite some variation in hydraulic properties. Estimated values for the preconsolidation pressure vary from $\sim 30-37 \mathrm{MPa}$, although this will vary for samples with a deeper burial history.

Hydraulic test data indicate a clear correlation between effective pressure and specific storage. Measured values for hydraulic permeability range from $\approx 2.1 \times 10^{-18}$ to $8.4 \times 10^{-21} \mathrm{~m}^{2}\left(2.1 \times 10^{-3}\right.$ to $8.5 \times 10^{-}$ ${ }^{6} \mathrm{mD}$ ), indicating a reasonable sealing capacity, especially at higher effective pressures. Under zero differential stress, hydraulic permeability is shown to reduce on loading at lower effective pressures, but becomes less sensitive to loading above $30 \mathrm{MPa}$. This may be explained by flow occurring in a localised fashion, rather than throughout the entire porosity of the material, despite the large test sample volumes.

A two-dimensional linear elastic finite element approach was used to model test data from each consolidation step. The results provide a good fit to test data and theoretical permeability measurements are in agreement with the experimental values measured for sample Mercia-3. Numerical permeability values for sample Mercia-2 differ from the experimental ones, thus indicating the importance of small-scale heterogeneity and localisation on flow behaviour. Findings demonstrate the influence of methodology (for example inducing flow through compression, as opposed to application of a constant head) on the resulting estimated permeabilities. Care should therefore be taken to select data acquired using the appropriate boundary conditions when applying observations to specific caprock scenarios.

Critical state yield envelopes constructed from test data were used to examine the influence of stress path and initial stress conditions on the potential for deformation, as a result of depletion and injection activities. Findings indicate the possibility of yield under a range of scenarios. Nevertheless, wet-side deformation is predicted in many cases, suggesting that permeability reduction will prevail in these scenarios. Yield is more likely for steeper stress paths, although it may also occur in other instances, when at greater depths. In some cases, where (i) material is weaker or (ii) at shallower depths and steeper stress paths, intersection close to the critical point or on the dry-side is also observed. Here, brittle, dilational behaviour is more likely to occur and the possibility of permeability enhancement cannot be discounted. As such, a range of outcomes may occur, the potential for which are strongly controlled by: (i) the initial stress conditions, (ii) the stress path gradient and (iii) variability in caprock strength resulting from lithological heterogeneity. Awareness of these controls may, therefore, aid in the selection of CCS sites with a favourable stress history, where caprock permeability is less likely to have been impacted by previous depletion activities.

In cases where yield on depletion occurs, inelastic deformation will also impact the return stress path on injection of carbon dioxide. The amount of deformation experienced will lead to stress path hysteresis and a greater chance of intersecting the dry-side of the envelope as pore pressures are elevated to their original values. In this case, key controlling factors will include: (i) the drainage condition of the caprock, (ii) the thickness of the sealing horizons and (iii) their initial permeability. 
Nevertheless, further work examining the post-yield phase is necessary in order to fully assess the geomechanical impact of stress changes during $\mathrm{CO}_{2}$ injection.

\section{Acknowledgements}

The study was undertaken by staff of the Minerals and Waste Programme of the British Geological Survey (BGS) using the experimental facilities of the Transport Properties Research Laboratory (TPRL). This work was supported by the Engineering and Physical Sciences Research Council [grant number: EP/K036025/1]. Co-funding for the study was provided by the BGS Geosphere Containment research project. Thanks go to Rob Cuss for discussion and editing, Matt Kirkham for grain density measurements, Andy Wiseall and Neil Stacey for sample preparation and the BGS Research and Development workshops for equipment design and machining. Material was collected with kind permission of the Irish Salt Mining \& Exploration Co. Ltd. Particular thanks go to Jason Hopps for his assistance and patience during sample collection. This paper is published with the permission of the Executive Director, British Geological Survey (NERC).

Appendix A1 -analysis of steady-state hydraulic responses

Darcy's Law gives the following relationship:

$$
K=-\frac{Q \rho_{w} g}{A_{s}} \frac{L_{s}}{\Delta P}
$$

where $Q$ is the steady-state flow $\left(\mathrm{m}^{3} . \mathrm{s}^{-1}\right) ; \rho_{w}$ is the porewater density $\left[\mathrm{kg} / \mathrm{m}^{3}\right] ; g$ is the acceleration due to gravity (9.81 m.s. $\left.\mathrm{s}^{-2}\right) ; A_{s}$ is the cross-sectional area of the test sample normal to flow $\left(\mathrm{m}^{2}\right) ; L_{s}$ is the sample length $(\mathrm{m})$; and $\Delta \mathrm{P}$ is the pressure drop along the sample $(\mathrm{Pa})$. Parameter $K$ is then the hydraulic conductivity $(\mathrm{m} / \mathrm{s})$. The equivalent intrinsic (or absolute) permeability term $\mathrm{k}\left(\mathrm{m}^{2}\right)$ is given by:

$$
k=-\frac{Q \mu_{w}}{A_{s}} \frac{\Delta L_{s}}{\Delta P}
$$

where $\mu_{\mathrm{w}}$ is the viscosity of water $\left(2.322 \times 10^{-3} \mathrm{~Pa} . \mathrm{s}\right)$.

For constant pressure tests, the difference between upstream and downstream water pressures $\left(\Delta \mathrm{P}_{\mathrm{w}}\right)$ at the steady-state asymptote of the flow transient was determined allowing hydraulic conductivity (K) to be calculated using (A1-2) by setting $\Delta \mathrm{P}=\Delta \mathrm{P}_{\mathrm{w}}$.

\section{References}


Armitage, P.J., Worden, R.H., Faulkner, D.R., Butcher, A.R. and Espie, A.A. (2016). Permeability of the Mercia Mudstone: suitability as caprock to carbon capture and storage sites. Geofluids, 16(1), pp.2642.

Atkinson, J.H.and Bransby, P.L. (1978). The Mechanics of Soils: An Introduction to Critical State Soil Mechanics. McGraw-Hill, London.

Baud, P., Schubnel, A. and Wong, T.F. (2000). Dilatancy, compaction, and failure mode in Solnhofen limestone. Journal of Geophysical Research: Solid Earth, 105(B8), pp.19289-19303.

Bentham M (2006) An assessment of carbon sequestration potential in the UK - Southern North Sea case study, Tyndall Centre for Climate Change Research, Working Paper 85.

Biot, M.A. (1941). General theory of three-dimensional consolidation. Journal of Applied Physics, 12, $155-164$.

Busch, A. and Amann-Hildenbrand, A. (2013). Predicting capillarity of mudrocks. Marine and Petroleum Geology, 45, pp.208-223.

Chandler, R.J. (1969). The effect of weathering on the shear strength properties of Keuper marl. Géotechnique, 19, pp. 321-334.

Cooke-Yarborough, P. (1991). The Hewett Field, Blocks 48/28-29-30, 52/4a-5a, UK North Sea in Abbots, I.L. (ed.), United Kingdom Oil and Gas Fields, 25 Years Commemorative Volume, Geological Society Memoir No. 14, pp.433-442.Cuss, R.J., Rutter, E.H., and Holloway, R.F. (2003). The Application of Critical State Soil Mechanics to the Mechanical Behaviour of Sandstone. International Journal of Rock Mechanics and Mining Sciences, 40, pp.847-862. doi: 10.1016/S13651609(03)00053-4.

Cuss, R.J., Graham, C.C., Wiseall, A.C, and Harrington, J.F. (2016) Cyclic loading of an idealized clayfilled fault; comparing hydraulic flow in two clay gouges. Geofluids, 16, pp.552-564. DOI: 10.1111/gfl.12175.

Fortin, J., Stanchits, S., Dresen, G. and Guéguen, Y. (2006). Acoustic emission and velocities associated with the formation of compaction bands in sandstone, Journal of Geophysical Research, 111, B10203, doi: 10.1029/2005JB003854.

Hallsworth, C.R., and Knox, R.W.O.'B. (1999). BGS Rock Classification Scheme Volume 3: Classification of sediments and sedimentary rocks. British Geological Survey Research Report, RR 9903.

Hangx, S., van der Linden, A., Marcelis, F. and Bauer, A. (2013). The effect of $\mathrm{CO}_{2}$ on the mechanical properties of the captain sandstone: geological storage of $\mathrm{CO}_{2}$ at the Goldeneye field UK. International Journal of Greenhouse Gas Control 19 (2013): 609-619.

Harrington, J.F. and Horseman, S.T. (1999). Gas transport properties of clays and mudrocks. In: Aplin, A.C., Fleet, A.J. and Macquaker, J.H.S. (eds) Muds and Mudstones: Physical and Fluid Flow Properties. Geol. Soc. London, Spec. Pub. 158, 107-124. 
Harrington, J. F., Birchall, D. J., Noy, D. J., Cuss, R. J., and Graham, C. (2011). Consolidation and mass transport properties of the Nordland Shale. Geophysical Research Abstracts, Vol. 13, EGU201112688.

Hettema, M., Papamichos, E. and Schutjens, P.M.T.M. (2002). Subsidence delay: field observations and analysis. Oil \& Gas Science and Technology, 57(5), pp.443-458.

Hobbs, P.R.N, Hallam, J.R., Forster, A., Entwisle, D.C., Jones, L.D, Cripps, A.C., Northmore, K.J., Self, S.J. and Meakin, J.L. (2002). Engineering geology of British rocks and soils - Mudstones of the Mercia Mudstone Group. British Geological Survey Research Report, RR/01/02.

Holt, R.M., Fjær, E., Raaen, A.M. and Ringstad, C. (1991). Influence of stress state and stress history on acoustic wave propagation in sedimentary rocks. In Shear Waves in Marine Sediments (pp. 167174). Springer Netherlands.

Horseman, S.T., Winter, M.G., Entwistle, D.C. (1993). Triaxial experiments on Boom Clay. In: Cripps, J.C., Coulthard, J.M., Culshaw, M.G., Forster, A., Hencher, S.R., Moon, C.F. (Eds.). The Engineering Geology of Weak Rock. Balkema, Rotterdam, 36-43.

Horseman, S.T., Higgo, J.J.W., Alexander, J. and Harrington, J.F. (1996). Water, gas and solute movement in argillaceous media. Rept. No. CC-96/1 to OECD/NEA Working Group on Measurement and Physical Understanding of Groundwater Flow through Argillaceous Media. Nuclear Energy Agency, OECD, Paris.ISBN 92-64-1488-1.

Horseman, S. (2001). Self-healing of fractures in argillaceous media from the geomechanical point of view. NEA/RWM/CLAYCLUB (2001) 5 Unclassified, p.19.

Horseman, S.T., Harrington, J.F., Birchall, D.J., Noy, D.J., Cuss, R.J. (2005). Consolidation and rebound properties of Opalinus Clay: a long-term, fully drained test. British Geological Survey, 72pp, $\mathrm{CR} / 05 / 128 \mathrm{~N}$.

Howard, A.S., Warrington, G., Ambrose, K., and Rees, J.G. (2008). A formational framework for the Mercia Mudstone Group (Triassic) of England and Wales. British Geological Survey Research Report, $\mathrm{RR} / 08 / 04$.

Hvorslev, M.J. (1937). Uber die fesigkeitseigenshaften gestorter bindinger boden, Ingvidensk. Skr., 45.

Johnson, H., Warrington, G., Stoker, S.J. (1994). Permian and Triassic of the Southern North Sea. In: Knox, R.W.O'B., Cordey, W.G. (eds) Lithostratigraphic nomenclature of the UK North Sea. British Geological Survey, Nottingham.

Jones, M.E. and Addis, M.A. (1986). The application of stress path and critical state analysis to sediment deformation. Journal of Structural Geology, 8(5), pp.575-580.

Ketter FJ (1991). The Esmond, Forbes and Gordon Fields, Blocks 43/8a, 43/13a, 43/15a, 43/20a, UK North Sea in Abbots, I.L. (ed.), United Kingdom Oil and Gas Fields, 25 Years Commemorative Volume, Geological Society Memoir No. 14, pp.425-432. 
Khan, A.S., Xiang, Y., Huang, S.J. (1991). Behavior of Berea sandstone under confining pressure Part 1: yield and failure surfaces, and nonlinear elastic response. International Journal of Plasticity 7, 607624.

Lewis, D., Bentham, M., Cleary, T., Vernon, R., O'Neill, N., Kirk, K., Chadwick, A., Hilditch, D., Karsten, M., Guy, A., Peter, N., Minh, H. (2009). Assessment of the potential for geological storage of carbon dioxide in Ireland and Northern Ireland. Energy Procedia, 1 (1). 2655-2662.

10.1016/j.egypro.2009.02.033.

Lynch, T., Fisher, Q., Angus, D. and Lorinczi, P. (2013). Investigating stress path hysteresis in a $\mathrm{CO}_{2}$ injection scenario using coupled geomechanical-fluid flow modelling. Energy Procedia, 37, $3833-$ 3841.

Manning, P. I., \& Wilson, H. E. (1975). The stratigraphy of the Larne Borehole, County Antrim. Bulletin of the Geological Survey of Great Britain, 50, 1-50.

Mott MacDonald. (2012). Potential cost reductions in CCS in the power sector.

Roscoe, K.H., Schofield, A. and Wroth, C.P. (1958). On the yielding of soils. Géotechnique, 8, pp. 2253.

Ruistuen, H., Teufel, L.W. and Rheff, D. (1999). Influence of reservoir stress path on deformation and permeability of weakly cemented sandstone reservoirs, Society of Petroleum Engineers Reservoir Evaluation and Engineering, 2(3), 266-272.

Schofield, A., and Wroth, C.P. (1968) Critical State Soil Mechanics. London, McGraw-Hill, 310 pp.

Schutjens, P.M.T.M., Hanssen, T.H., Hettema, M.H.H., Merour, J., de Bree, J.P., Coremans, J.W.A. and Helliesen, G. (2004). January. Compaction-induced porosity/permeability reduction in sandstone reservoirs. In SPE Annual Technical Conference and Exhibition. Society of Petroleum Engineers, 202216.

Scott, C. R. (1980). An Introduction to Soil Mechanics and Foundations. 3rd Edition. Applied Science Publishers LTD.

Seedhouse, J. K., \& Racey, A. (1997). Sealing capacity of the Mercia Mudstone Group in the East Irish Sea Basin: implications for petroleum exploration. Journal of Petroleum Geology, 20(3), 261-286.

Segall, P. (1985). Stress and subsidence resulting from subsurface fluid withdrawal in the epicentral region of the 1983 Coalinga earthquake. Journal of Geophysical Research: Solid Earth, 90(B8), pp.6801-6816.

Segall, P. (1989). Earthquakes triggered by fluid extraction. Geology, 17(10), pp.942-946.

Segall, P. and Fitzgerald, S.D. (1998). A note on induced stress changes in hydrocarbon and geothermal reservoirs. Tectonophysics, 289(1), pp.117-128.

Shah, K. (1997). An elasto-plastic constitutive model for brittle-ductile transition in porous rocks. Proceedings of the 29th Symposium on Fatigue and Fracture Mechanics, ASTM, Standford, California, June 1997. 
Sheldon, H.A., Barnicoat, A.C. and Ord, A. (2006). Numerical modelling of faulting and fluid flow in porous rocks: an approach based on critical state soil mechanics. Journal of Structural Geology, 28(8), pp.1468-1482.

Shelton, R. (1997). Tectonic evolution of the Larne Basin. Geological Society, London, Special Publications, 124(1), pp.113-133.

Vajdova, V., Zhu, W., Chen, T.M.N. and Wong, T.F. (2010). Micromechanics of brittle faulting and cataclastic flow in Tavel limestone. Journal of Structural Geology, 32(8), pp.1158-1169.

Whitlow, R. (2001). Basic soil mechanics. Pearson Prentice Hall, fourth edition, ISBN 0582-38109-6.

Williams, J.D.O., Holloway, S. and Williams, G.A. (2014). Pressure constraints on the $\mathrm{CO}_{2}$ storage capacity of the saline water-bearing parts of the Bunter Sandstone Formation in the UK Southern North Sea. Petroleum Geoscience, 20(2), pp.155-167.

Wilson A.A. (1993). The Mercia Mudstone Group (Trias) of the Cheshire Basin. Proceedings of the Yorkshire Geological Society, Vol. 49, Part 3, PP. 171-188.

Wong, T.F., David, C. and Zhu, W. (1997). The transition from brittle faulting to cataclastic flow in porous sandstones: Mechanical deformation. Journal of Geophysical Research: Solid Earth, 102(B2), pp.3009-3025.

Wong, T.F. and Baud, P. (2012). The brittle-ductile transition in porous rock: A review. Journal of Structural Geology, 44, pp.25-53.

Yang, Y. and Aplin, A.C. (2007). Permeability and petrophysical properties of 30 natural mudstones, Journal of Geophysical Research, 112, B03206, doi: 10.1029/2005JB004243.

Zhu, W.L., Wong, T.F. (1997). The transition from brittle faulting to cataclastic flow: permeability evolution. Journal of Geophysical Research 102, 3027-3041.

Zoback, M. D. (2010). Reservoir geomechanics. Cambridge University Press. 